Review

\title{
From Protein Engineering to Immobilization: Promising Strategies for the Upgrade of Industrial Enzymes
}

\author{
Raushan Kumar Singh, Manish Kumar Tiwari, Ranjitha Singh and Jung-Kul Lee * \\ Department of Chemical Engineering, Konkuk University, 1 Hwayang-Dong, Gwangjin-Gu, \\ Seoul 143-701, Korea; E-Mails: singhraushank@gmail.com (R.K.S.); tiwari@konkuk.ac.kr (M.K.T.); \\ ranjita.rsingh@gmail.com (R.S.)
}

* Author to whom correspondence should be addressed; E-Mail: jkrhee@konkuk.ac.kr; Tel.: +82-2-450-3505; Fax: +82-2-458-3504.

Received: 3 September 2012; in revised form: 14 November 2012 / Accepted: 24 December 2012 / Published: 10 January 2013

\begin{abstract}
Enzymes found in nature have been exploited in industry due to their inherent catalytic properties in complex chemical processes under mild experimental and environmental conditions. The desired industrial goal is often difficult to achieve using the native form of the enzyme. Recent developments in protein engineering have revolutionized the development of commercially available enzymes into better industrial catalysts. Protein engineering aims at modifying the sequence of a protein, and hence its structure, to create enzymes with improved functional properties such as stability, specific activity, inhibition by reaction products, and selectivity towards non-natural substrates. Soluble enzymes are often immobilized onto solid insoluble supports to be reused in continuous processes and to facilitate the economical recovery of the enzyme after the reaction without any significant loss to its biochemical properties. Immobilization confers considerable stability towards temperature variations and organic solvents. Multipoint and multisubunit covalent attachments of enzymes on appropriately functionalized supports via linkers provide rigidity to the immobilized enzyme structure, ultimately resulting in improved enzyme stability. Protein engineering and immobilization techniques are sequential and compatible approaches for the improvement of enzyme properties. The present review highlights and summarizes various studies that have aimed to improve the biochemical properties of industrially significant enzymes.
\end{abstract}

Keywords: immobilization; inhibition; protein engineering; selectivity; stability 


\section{Introduction}

Biocatalysts are extensively used in the industrial production of bulk chemicals and pharmaceuticals, and over 300 processes have already been implemented [1]. In the vast majority of processes, native microbial enzymes of microbial with that exhibit the desired properties are used. Often, for a given biocatalytic process, the native enzyme does not meet the requirements for large-scale application, and its properties thus need to be optimized or modulated. Many industrial enzymes, such as lipases, with a wide range of substrate specificities, are utilized in many processes, often compromising the desired productivity. The role of protein engineering is to overcome the limitations of natural enzymes as biocatalysts and engineer process-specific biocatalysts. This includes optimizing the chemoselectivity, regioselectivity, and, especially, stereoselectivity of the biocatalyst, as well as process-related aspects, such as long-term stability at certain temperatures or $\mathrm{pH}$-values and activity in the presence of high substrate concentrations to achieve maximal productivity. Some improvement in process efficiency can be achieved by modifying the chemical manufacturing process to suit the sensitivities of the biocatalyst (e.g., in terms of $\mathrm{pH}$, temperature, and solvents). The other alternative is to use protein engineering methodologies to generate new biocatalysts to function under more ideal process conditions, followed by immobilization to establish more robust processes. Due to recent advances in protein engineering techniques, numerous examples of the optimization of certain enzyme traits (e.g., thermostability, tolerance towards organic solvents, enantioselectivity) have been reported. This has been achieved both by developing new screening systems and by advancements in the understanding of protein structure. Rational protein design by default variants with very few amino acid exchanges and simultaneous saturation mutagenesis allows the generation of synergistic effects of neighboring mutations. On the other hand, semi-rational approaches have recently been shown to be very efficient in cases where the key amino acids governing the property of interest are known [2]. The choice of method therefore is still a case-to-case decision, depending on the property of interest and existing structural and mechanistic knowledge, as well as on practical considerations, such as the availability of a high-throughput screening or selection system.

Enzymes are considered to be sensitive, unstable at elevated temperatures, and require an aqueous medium for function; these are features that are not ideal for a catalyst, and are undesirable in most syntheses. In many cases a simple way to avoid at least some of these drawbacks is to immobilize enzymes [3]. The immobilization of enzymes has proven particularly valuable and has been exploited over the last four decades to enhance enzyme properties such as activity, stability, and substrate specificity for their successful utilization in industrial processes (Figure 1). In spite of the long history and obvious advantages of enzyme immobilization [4], Straathof et al. (2002) estimated that only 20\% of biocatalytic processes involve immobilized enzymes [5]. Initially, the main challenge was to find suitable immobilization methods to allow multiple uses of enzymes for the same reaction. With the advancement in immobilization techniques, the focus has shifted to the development of modulated enzymes with the desired properties for certain specific applications. Immobilization has its associated advantages (it allows for multiple, repetitive, or continuous use and has minimum reaction time, high stability, improved process control, multienzyme system, easy product separation, while it is less labor intensive and more cost effective, safe to use, and environmentally friendly) [6] and disadvantages (its lowered activity, conformational change of the enzyme, possibility of enzyme denaturation, 
changes in properties, mass transfer limitations, and lowered efficacy against insoluble substrates). This review covers different strategies of protein engineering and immobilization to modulate the properties of enzymes to suit industrial processes.

Figure 1. Evolvable enzyme properties for its successful utilization in industrial processes.

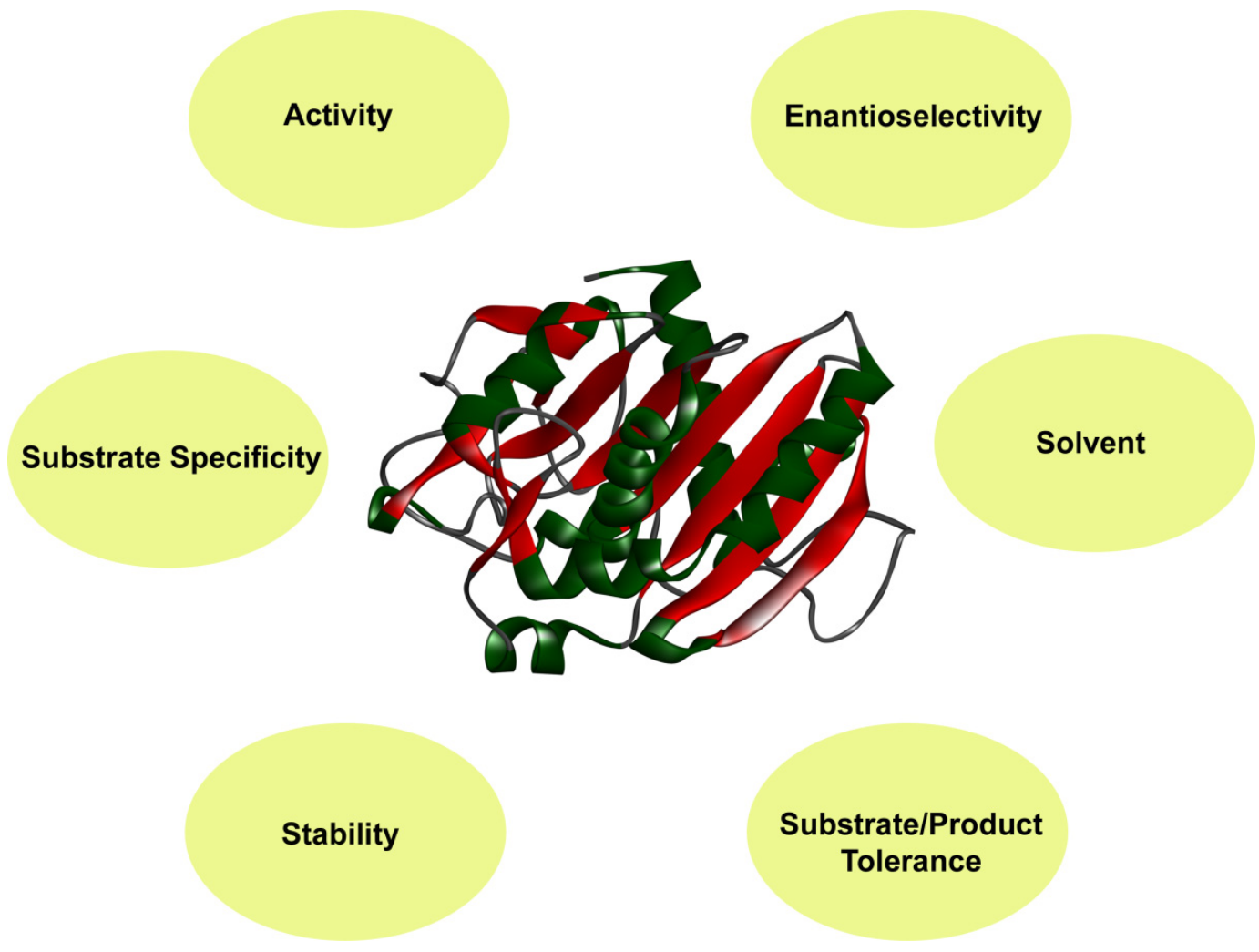

\section{Protein Engineering to Upgrade Industrial Enzymes}

In the past few decades, biocatalysts have been successfully exploited for the synthesis of various complex drug intermediates, speciality chemicals, and even commodity chemicals in the pharmaceutical, chemical, and food industries due to their inherent ability to catalyze reactions with high velocity and unmet specificity under a variety of conditions, as well as their potential as a greener alternative to chemical catalysts. The increasing interest in applying enzymes in industrial and household catalysis has spurred the development of protein engineering methodologies for novel biocatalysts with new or improved properties. Recent advances in recombinant DNA technology, high throughput technology, genomics, and proteomics have fueled the development of new biocatalysts and biocatalytic processes. Since the beginning of large-scale (recombinant) enzyme production for industrial applications, protein engineering has emerged as a powerful tool to improve enzyme properties. Enzymes with the desired properties such as enhanced activity, high thermostabilty, and specificity under industrial conditions can be obtained by optimizing process conditions and by protein engineering (Table 1). 
Table 1. List of the enzymes engineered by protein engineering.

\begin{tabular}{|c|c|c|c|c|c|}
\hline Enzyme & Organism & Improved property & Method & Application & Reference \\
\hline Hydantoinase & Arthrobacter sp. & $\begin{array}{l}\text { Enantioselective hydantoinase and 5-fold } \\
\text { more productivity }\end{array}$ & $\begin{array}{l}\text { Saturation mutagenesis, } \\
\text { screening }\end{array}$ & $\begin{array}{c}\text { Production of L-Met } \\
\text { (L-amino acids) }\end{array}$ & [7] \\
\hline $\begin{array}{l}\text { Cyclodextrin } \\
\text { glucanotransferase }\end{array}$ & $\begin{array}{l}\text { Bacillus } \\
\text { stearothermophilus } \text { ET1 }\end{array}$ & $\begin{array}{c}\text { Modulation of cyclizing activity and } \\
\text { thermostability }\end{array}$ & Site-directed mutagenesis & Bread industry & [8] \\
\hline Lipase B & Candida antarctica & $\begin{array}{l}\text { 20-fold increase in half-life at } \\
\qquad 70^{\circ} \mathrm{C}\end{array}$ & epPCR & $\begin{array}{c}\text { Resolution and } \\
\text { desymmetrization of compound }\end{array}$ & [9] \\
\hline $\begin{array}{c}\text { Tagatose-1,6-Bisphosphate } \\
\text { aldolase }\end{array}$ & E. coli & $\begin{array}{l}80 \text {-fold improvement in } \mathrm{k}_{\mathrm{cat}} / \mathrm{K}_{\mathrm{m}} \text { and } \\
100 \text {-fold change in stereospecificity }\end{array}$ & $\begin{array}{l}\text { DNA shuffling and } \\
\text { screening }\end{array}$ & $\begin{array}{l}\text { Efficient syntheses of complex } \\
\text { stereoisomeric products }\end{array}$ & {$[10]$} \\
\hline Xylose isomerase & Thermotoga neapolitana & $\begin{array}{l}\text { High activity on glucose at low } \\
\text { temperature and low } \mathrm{pH}\end{array}$ & $\begin{array}{l}\text { Random Mutagenesis } \\
\text { and screening }\end{array}$ & $\begin{array}{l}\text { Used in preparation of high } \\
\text { fructose syrup }\end{array}$ & {$[11]$} \\
\hline Amylosucrase & Neisseria polysaccharea & 5-fold increased activity & $\begin{array}{l}\text { Random mutagenesis, } \\
\text { gene shuffling, } \\
\text { and directed evolution }\end{array}$ & $\begin{array}{l}\text { Synthesis or the modification } \\
\text { of polysaccharides }\end{array}$ & {$[12]$} \\
\hline Galactose oxidase & $F$. graminearum & $\begin{array}{l}\text { 3.4-4.4 fold greater } \mathrm{V}_{\max } / \mathrm{K}_{\mathrm{m}} \text { and } \\
\text { increased specificity }\end{array}$ & epPCR and screening & Derivatization of guar gum & {$[13]$} \\
\hline $\begin{array}{c}\text { Fructose bisphosphate } \\
\text { aldolase }\end{array}$ & E. coli & $\begin{array}{l}\text { Increased thermostablity and stability to } \\
\text { treatment with organic solvent }\end{array}$ & DNA shuffling & Use in organic synthesis & {$[14]$} \\
\hline $1,3-1,4-\alpha$-D-glucanase & Fibrobacter succinogenes & $3-4$-fold increase in the turnover rate $(\mathrm{k})$ & PCR-based gene truncation & Beer industry & {$[15]$} \\
\hline Lipase & P. aeruginosa & 2-fold increase in amidase activity & $\begin{array}{l}\text { Random mutagenesis and } \\
\text { screening }\end{array}$ & $\begin{array}{l}\text { Understanding lipase inability } \\
\text { to hydrolyze amides }\end{array}$ & {$[16]$} \\
\hline Protease BYA & Bacillus sp. Y & Specific activity 1.5 -fold higher & Site-directed mutagenesis & Detergents products & [17] \\
\hline $\begin{array}{l}p \text {-Hydroxybenzoate } \\
\text { hydroxylase }\end{array}$ & $\begin{array}{l}\text { Pseudomonas fluorescens } \\
\text { NBRC } 14160\end{array}$ & $\begin{array}{l}\text { Activity, reaction specificity, } \\
\text { and thermal stability }\end{array}$ & Combinatorial mutagenesis & $\begin{array}{c}\text { Degrading various aromatic } \\
\text { compounds in the } \\
\text { environment }\end{array}$ & {$[18]$} \\
\hline Endo-1,4- $\beta$-xylanase II & Trichoderma reesei & Increased alkali stability & Site-directed mutagenesis & Sulfate pulp bleaching & [19] \\
\hline Xylose isomerase & Thermotoga neapolitana & 2.3-fold increases in catalytic efficiency & Random mutagenesis & $\begin{array}{l}\text { Production of high fructose } \\
\text { corn syrup }\end{array}$ & {$[11]$} \\
\hline
\end{tabular}


Table 1. Cont.

\begin{tabular}{|c|c|c|c|c|c|}
\hline Enzyme & Organism & Improved property & Method & Application & Reference \\
\hline$\alpha$-Amylase & Bacillus sp. TS-25 & $10{ }^{\circ} \mathrm{C}$ enhancement in thermal stability & Directed evolution & Baking industry & {$[20]$} \\
\hline Xylanase & & $\mathrm{Tm}$ improved by $25^{\circ} \mathrm{C}$ & $\begin{array}{l}\text { Gene site-saturation } \\
\text { mutagenesis }\end{array}$ & Degradation of hemicellulose & {$[21]$} \\
\hline Fructosyl peptide oxidase & Coniochaeta sp & 79.8-fold enhanced thermostability & $\begin{array}{l}\text { Directed evolution and } \\
\text { site-directed mutagenesis }\end{array}$ & Clinical diagnosis & {$[22]$} \\
\hline Endo- $\beta$-1,4-xylanase & Bacillus subtilis & Acid stability & $\begin{array}{l}\text { Rational protein } \\
\text { engineering }\end{array}$ & Degradation of hemicellulose & [23] \\
\hline Subtilase & Bacillus sp. & $\begin{array}{l}6 \text {-fold increase in caseinolytic activity at } \\
\qquad 15-25^{\circ} \mathrm{C}\end{array}$ & $\begin{array}{c}\text { Directed evolution and } \\
\text { site-directed mutagenesis }\end{array}$ & $\begin{array}{l}\text { Detergent additives and food } \\
\text { processing }\end{array}$ & {$[24]$} \\
\hline CotA laccase & B. subtilis & 120 -fold more specific for ABTS & Directed evolution & $\begin{array}{l}\text { Catalyze oxidation of } \\
\text { polyphenols }\end{array}$ & {$[25]$} \\
\hline Pyranose 2-oxidase & Trametes multicolor & $\begin{array}{l}\text { Altered substrate selectivity for } \\
\text { D-galactose, D-glucose }\end{array}$ & $\begin{array}{l}\text { Semi-rational enzyme } \\
\text { engineering approach }\end{array}$ & Food industry & {$[26]$} \\
\hline Xylanase XT6 & $\begin{array}{c}\text { Geobacillus } \\
\text { stearothermophilus }\end{array}$ & $\begin{array}{l}\text { 52-fold enhancement in thermostability; } \\
\text { increased catalytic efficiency }\end{array}$ & $\begin{array}{l}\text { Directed evolution and } \\
\text { site-directed mutagenesis }\end{array}$ & Degradation of hemicellulose & {$[27]$} \\
\hline Lipase & Bacillus pumilus & Thermostability and 4-fold increase in $\mathrm{k}_{\mathrm{cat}}$ & Site-directed mutagenesis & $\begin{array}{c}\text { Chemical, food, leather and } \\
\text { detergent industries }\end{array}$ & {$[28]$} \\
\hline Bgl-licMB & $\begin{array}{c}\text { Bacillus amyloliquefaciens } \\
\text { (Bgl) and Clostridium } \\
\text { thermocellum (licMB) }\end{array}$ & $\begin{array}{l}2.7 \text { and } 20 \text {-fold higher } \mathrm{k}_{\mathrm{cat}} / \mathrm{K}_{\mathrm{m}} \text { than that of } \\
\text { the parental } \mathrm{Bgl} \text { and licMB, respectively }\end{array}$ & $\begin{array}{l}\text { Splicing-by-overlap } \\
\text { extension }\end{array}$ & $\begin{array}{c}\text { Brewing and animal-feed } \\
\text { industries }\end{array}$ & [29] \\
\hline$\beta$-agarase AgaA & Zobellia galactanivorans & Catalytic activity and thermostability & Site-directed mutagenesis & $\begin{array}{c}\text { Production of functional } \\
\text { neo-agarooligosaccharides }\end{array}$ & {$[30]$} \\
\hline Prolidase & Pyrococcus horikoshii & Thermostability & Random mutagenesis & $\begin{array}{c}\text { Detoxification of } \\
\text { organophosphorus } \\
\text { nerve agents }\end{array}$ & {$[31]$} \\
\hline
\end{tabular}


Table 1. Cont.

\begin{tabular}{|c|c|c|c|c|c|}
\hline Enzyme & Organism & Improved property & Method & Application & Reference \\
\hline Lipases & Geobacillus sp. NTU 03 & $\begin{array}{l}\text { 79.4-fold increment in activity; } \\
\text { 6.3-79-fold enhanced thermostability }\end{array}$ & $\begin{array}{c}\text { Error-prone PCR and } \\
\text { site-saturation mutagenesis }\end{array}$ & Transesterification & {$[32]$} \\
\hline Xylanase & Hypocrea jecorina & Thermostability & $\begin{array}{l}\text { Look-through mutagenesis } \\
\text { (LTMTM) and } \\
\text { combinatorial beneficial } \\
\text { mutagenesis (CBMTM) }\end{array}$ & Degradation of hemicellulose & {$[33]$} \\
\hline Amylase & Bacillus sp. US149 & Thermostability & Site-directed mutagenesis & Bread industry & {$[34]$} \\
\hline Cholesterol oxidase & Brevibacterium sp. & Thermostability and enzymatic activity & Site-directed mutagenesis & $\begin{array}{c}\text { Detection and conversion of } \\
\text { cholesterol }\end{array}$ & {$[35]$} \\
\hline Lipase B & Candida antarctica & Enhancement of thermostability & $\begin{array}{c}\text { Molecular dynamics (MD) } \\
\text { simulation and site-directed } \\
\text { mutagenesis }\end{array}$ & Detergent industries & {$[36]$} \\
\hline Laccase & Bacillus HR03 & 3 -fold improved $\mathrm{k}_{\text {cat }}$ and thermostability & Directed mutagenesis & $\begin{array}{l}\text { Catalyze oxidation of } \\
\text { polyphenols, and polyamines }\end{array}$ & {$[37]$} \\
\hline D-psicose 3-epimerase & Agrobacterium tumefaciens & Thermostability & $\begin{array}{c}\text { Random and } \\
\text { site-directed mutagenesis }\end{array}$ & $\begin{array}{l}\text { Industrial producer of } \\
\text { D-psicose }\end{array}$ & {$[38]$} \\
\hline $1,3-1,4-\beta$-D-glucanase & Fibrobacter succinogenes & Thermostability and specific activity & Rational mutagenesis & Widely used as a feed additive & {$[39]$} \\
\hline$\alpha$-Amylase & Bacillus licheniformis & Acid stability & Direct evolution & Starch hydrolysis & {$[40]$} \\
\hline Alkaline amylase & Alkalimonas amylolytica & Oxidative stability & Site-directed mutagenesis & $\begin{array}{l}\text { Detergent and textile } \\
\text { industries }\end{array}$ & {$[41]$} \\
\hline Endoglucanase & Thermoascus aurantiacus & $\begin{array}{l}\text { 4-fold increase in } \mathrm{k}_{\text {cat }} \text { and } 2.5 \text {-fold } \\
\text { improvement in hydrolytic activity on } \\
\text { cellulosic substrates }\end{array}$ & Site-directed mutagenesis & Bioethanol production & [42] \\
\hline $\begin{array}{c}\text { D-glucose } \\
\text { 1-dehydrogenase } \\
\text { isozymes }\end{array}$ & Bacillus megaterium & Substrate specificity & Site-directed mutagenesis & $\begin{array}{l}\text { Measurements of blood } \\
\text { glucose level }\end{array}$ & {$[43]$} \\
\hline Glycerol dehydratase & Klebsiella pneumoniae & $\begin{array}{l}\text { 2-fold pH stability; } \\
\text { enhanced specific activity }\end{array}$ & Rational design & $\begin{array}{c}\text { Synthesis of } \\
\text { 1,3-Propanediol }\end{array}$ & {$[44]$} \\
\hline
\end{tabular}


Table 1. Cont.

\begin{tabular}{|c|c|c|c|c|c|}
\hline Enzyme & Organism & Improved property & Method & Application & Reference \\
\hline $\begin{array}{c}\text { Cyclodextrin } \\
\text { Glucanotransferase }\end{array}$ & Bacillus sp. G1 & Enhancement of thermostability & Rational mutagenesis & $\begin{array}{l}\text { Starch is converted into } \\
\text { cyclodextrins }\end{array}$ & {$[45]$} \\
\hline Cellobiose phosphorylase & Clostridium thermocellum & Enhancement of thermostability & $\begin{array}{l}\text { Combined rational and } \\
\text { random approaches }\end{array}$ & Phosphorolysis of cellobiose & {$[46]$} \\
\hline Superoxide dismutase & Potentilla atrosanguinea & Thermostability & Site-directed mutagenesis & Scavenging of $\mathrm{O}_{2}^{-}$ & {$[47]$} \\
\hline Endoglucanase Cel8A & Clostridium thermocellum & Thermostability & $\begin{array}{l}\text { Consensus-guided } \\
\text { mutagenesis }\end{array}$ & $\begin{array}{l}\text { Conversion of cellulosic } \\
\text { biomass to biofuels }\end{array}$ & {$[48]$} \\
\hline Endo $\beta$-glucanase EgI499 & Bacillus subtilis JA18 & $\begin{array}{l}\text { Increase in half life from } 10 \text { to } 29 \text { mins at } \\
\qquad 65^{\circ} \mathrm{C}\end{array}$ & $\begin{array}{l}\text { Deletion of } C \text {-terminal } \\
\text { region }\end{array}$ & Animal feed production & [49] \\
\hline Pyranose 2-oxidase & Trametes multicolor & $\begin{array}{l}\text { Increase half life from } 7.7 \mathrm{~min} \text { to } \\
\qquad 10 \mathrm{~h}\left(\text { at } 60^{\circ} \mathrm{C}\right)\end{array}$ & Designed triple mutant & Food industry & {$[50]$} \\
\hline Xylanase XT6 & $\begin{array}{l}\text { Geobacillus } \\
\text { stearothermophilus }\end{array}$ & $\begin{array}{c}52 \times \text { increase in thermal stability, } \\
\mathrm{k}_{\text {opt }} \text { increase by } 10^{\circ} \mathrm{C} \text {, catalytic efficiency } \\
\text { increase by } 90 \%\end{array}$ & $\begin{array}{c}\text { Directed evolution and } \\
\text { site-directed mutagenesis }\end{array}$ & Biobleaching & {$[27]$} \\
\hline Tyrosine phenol-lyase & Symbiobacterium toebi & $\begin{array}{l}\text { Improved thermal stability and activity } \\
\text { (Increase in } \mathrm{T}_{\mathrm{m}} \text { up to } 11.2^{\circ} \mathrm{C} \text { ) }\end{array}$ & $\begin{array}{l}\text { Directed evolution (random } \\
\text { mutagenesis, reassembly } \\
\text { and activity screening) }\end{array}$ & $\begin{array}{l}\text { Industrial production of } \\
\text { 1-tyrosine and its derivatives }\end{array}$ & {$[51]$} \\
\hline Phytase & Penicilium sp. & Increased thermal stability & $\begin{array}{l}\text { Random mutation and } \\
\text { selection }\end{array}$ & Feed additives & {$[52]$} \\
\hline L-Asparaginase & Erwinia carotovora & Increase in half-life from 2.7 to $159.7 \mathrm{~h}$ & In vitro directed evolution & Therapeutic agent & {$[53]$} \\
\hline Endoglucanase CelA & Clostridium thermocellum & $\begin{array}{l}\text { 10-fold increase in half-life of } \\
\text { inactivation at } 86^{\circ} \mathrm{C}\end{array}$ & Saturation mutagenesis & $\begin{array}{l}\text { Bioconversion of cellulosic } \\
\text { biomass }\end{array}$ & {$[54]$} \\
\hline$\beta$-glucosidase $\mathrm{BglC}$ & Thermobifida fusca & $\begin{array}{l}\text { Increase in half-life from } 12 \text { to } \\
\qquad 1244 \mathrm{~min}\end{array}$ & $\begin{array}{c}\text { Family shuffling, site } \\
\text { saturation, and site-directed } \\
\text { mutagenesis }\end{array}$ & $\begin{array}{l}\text { Bioconversion of cellulosic } \\
\text { biomass }\end{array}$ & {$[55]$} \\
\hline Phospholipase D & Streptomyces & Improved thermal stability and activity & $\begin{array}{c}\text { Semi-rational, site-specific } \\
\text { saturation mutagenesis }\end{array}$ & Phosphatidylinositol synthesis & {$[56]$} \\
\hline
\end{tabular}


Table 1. Cont.

\begin{tabular}{|c|c|c|c|c|c|}
\hline Enzyme & Organism & Improved property & Method & Application & Reference \\
\hline$\beta$-glucosidase & Trichoderma reesei & $\begin{array}{c}\text { Enhanced } \mathrm{k}_{\mathrm{cat}} / \mathrm{K}_{\mathrm{m}} \text { and } \mathrm{k}_{\mathrm{cat}} \text { values by } \\
5.3 \text { - and } 6.9 \text {-fold }\end{array}$ & Site-directed mutagenesis & $\begin{array}{l}\text { Hydrolysis of cellobiose and } \\
\text { cellodextrins }\end{array}$ & {$[57]$} \\
\hline Lipases & & 144-fold enhanced thermostability & Error prone PCR & $\begin{array}{l}\text { Synthesis and hydrolysis of } \\
\text { long chain fatty acids }\end{array}$ & {$[58]$} \\
\hline Laccase & Pycnoporus cinnabarinus & 8000 -fold increase in $\mathrm{k}_{\mathrm{cat}} / \mathrm{K}_{\mathrm{m}}$ & $\begin{array}{c}\text { Directed evolution and } \\
\text { semi-rational engineering }\end{array}$ & $\begin{array}{c}\text { Lignocellulose biorefineries, } \\
\text { organic synthesis, and } \\
\text { bioelectrocatalysis }\end{array}$ & {$[59]$} \\
\hline Feruloyl esterase A & Aspergillus niger & Increase in half-life from 15 to $>4000 \mathrm{~min}$ & $\begin{array}{c}\text { Random and site-directed } \\
\text { mutagenesis }\end{array}$ & Degradation of lignocellulose & {$[60]$} \\
\hline
\end{tabular}




\subsection{Activity}

Improving the activity of an industrial enzyme is often a primary goal. This is partly because naturally available enzymes are usually not optimally suited for many processes in industrial applications. Many industrial enzymes, such cellulases, amylases, lipases, and even proteases, act on insoluble substrates. Therefore, the rate of substrate turnover may be limited by diffusion, and controlled by enzyme mobility at the surface or by on/off enzyme desorption rates [61]. These, in turn, are often related to the surface properties of the enzyme and the conditions at the interface between the enzyme and substrate [62]. A comparative study of the experimental results from several site-directed variants with structural modeling of fungal lipase from Rhizopuss oryzae has provided much insight into the molecular mechanism of catalysis [63]. Substitutions at Glu87 and Trp89 in the lid region have been suggested to alter the activity of the lipase from Humicola lanuginosa (lipolase) [64].

Cellulases and xylanase have become major focus in recent years due to their ability to provide the soft feel of stone-washed jeans in textile processing, fabric care benefits (such as color crispness) when used in laundry detergents [65], and reduction of the quantity of chemicals required for bleaching in the pulp and paper industry, thereby minimizing environmental impact [66]. Tyr169 in the Trichoderma reesei cellobiohydrolase II catalytic domain plays an important role in distorting the glucose ring into a more reactive conformation [67]. A detailed discussion of different families of xylanases and their structure and activity is provided in a review article [68] in Current Opinion in Biotechnology.

\subsection{Thermal Stability}

Enhanced thermostability is one of the most common properties desired as output from a protein engineering study and is often an important economic factor. The stability of an enzyme is affected by many factors, such as temperature, $\mathrm{pH}$, solvent, and the presence of surfactants. Among all possible deactivating factors, temperature is the best studied. At elevated temperatures, many enzymes tend to become (partly) unfolded and/or inactivated, meaning that they are no longer able to perform the desired tasks. There are two types of protein stability, thermodynamic and long-term, that are crucial from an applied perspective. Numerous protein engineering strategies have been reported in the last 10 years. Site-directed mutagenesis (SDM) and directed evolution have been exploited to engineer catalysts with improved thermostability (Figure 2). However, a combination of both strategies is becoming popular among researchers. Cherry et al. (1999) reported a combination of rational engineering and directed evolution techniques to improve the resistance of a fungal peroxidase towards hydrogen peroxide and high temperature, at high $\mathrm{pH}$, with the aim of making the enzyme better suited for laundry applications [69]. They obtained an enzyme variant with drastically improved thermal stability (200-fold greater than that of the wild-type enzyme) under conditions that mimic those in a washing machine. In another early study, Martin et al. (2001) described the stabilization of a cold-shock protein from B. subtilis (Bs-Csp) [70]. The size of the library was limited by the transformation efficiency of Escherichia coli, but still amounted to a respectable 107 variants. After six rounds of phage selection from 107 variants, five variants displayed increased stability. The most stable variant, displaying a remarkable improvement in $\mathrm{T}_{\mathrm{m}}$ (a $22{ }^{\circ} \mathrm{C}$ increase), differed at six 
randomized positions from its mesophilic parent. Very few charged residues were found in the selection, which might be related to the use of guanidine hydrochloride $(\mathrm{GdmHCl})$ in the selection scheme. After applying several selection regimes (temperature, amount of protease), mutants displaying up to a $28{ }^{\circ} \mathrm{C}$ increase in $\mathrm{T}_{\mathrm{m}}$ were obtained. The best mutant from the thermal screen differed at all six positions from the wild-type, the thermostable counterpart, Bc-Csp, and from the variant obtained by $\mathrm{GdmHCl}$ selection. Palackal et al. (2004) reported one of the highest stabilizations ever obtained by enzyme engineering (increase in $\mathrm{T}_{\mathrm{m}}$ of over $30^{\circ} \mathrm{C}$ ) [71]. Their starting point was a xylanase that was discovered by screening 50,000 plaques from a complex environmental DNA library derived from a sample of fresh bovine manure. The use of site-saturation mutagenesis and the screening of approximately 70,000 clones led to the identification of nine interesting mutations, which, when combined, increased the $\mathrm{Tm}$ by $34.2^{\circ} \mathrm{C}$.

Figure 2. Schematic representation of protein engineering strategies. Engineering method should be selected on the basis of the structural and mechanistic information and the feasibility of a high-throughput screening (HTS) system for screening or selection.

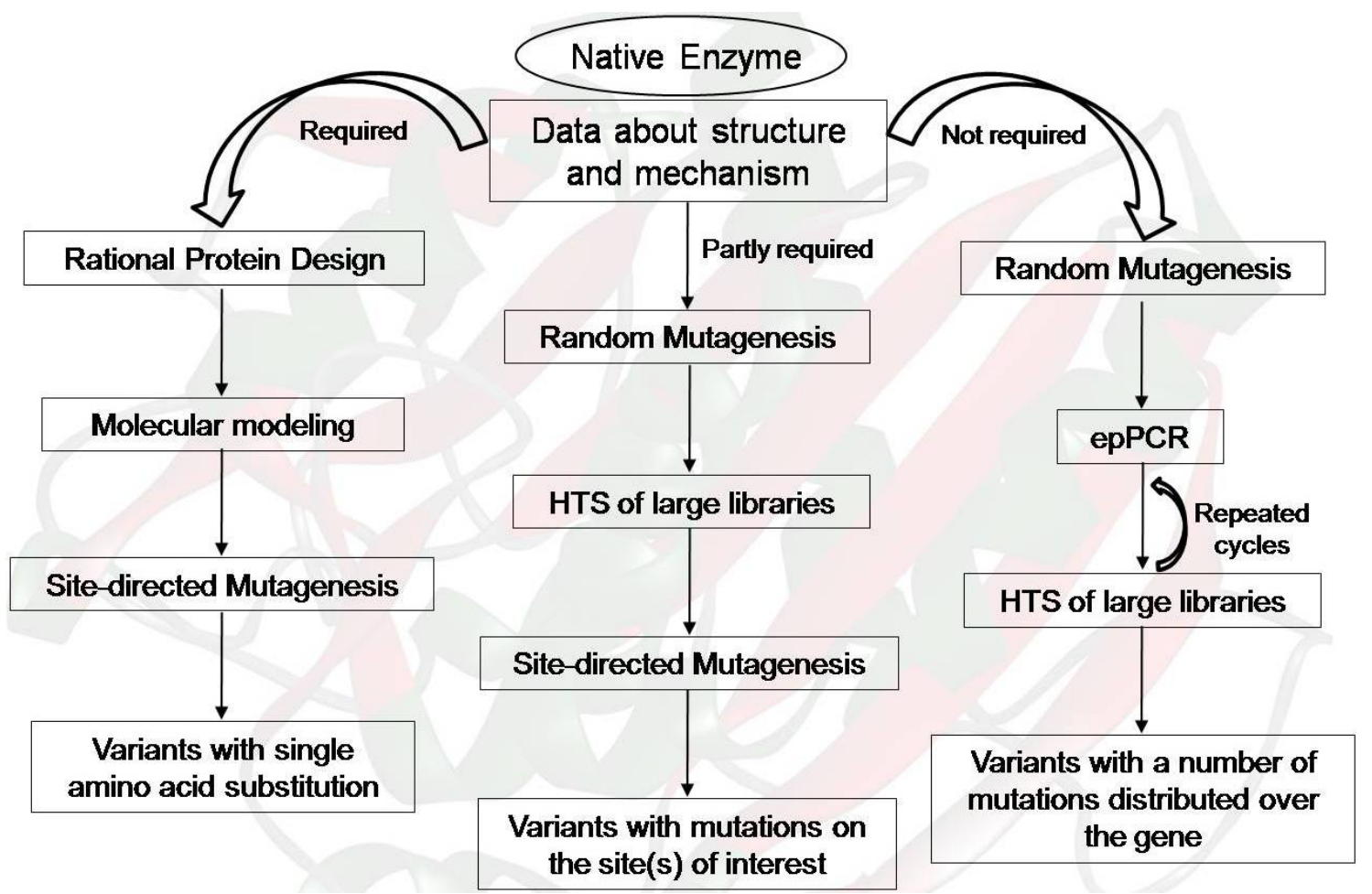

Directed evolution is a powerful engineering method, and it is often used to design enzymes with increased thermostability [72]. By screening for initial activity and residual activity at an elevated temperature, both the thermostability and activity of mesophilic subtilisin E [73], psychrophilic subtilisin S41 [74] and mesophilic p-nitrobenzyl esterase [75] were significantly increased using directed evolution strategies. Enzymes that have been improved by directed evolution have already been commercialized [72]. A major advantage of this engineering method over SDM is that no knowledge about enzyme structure is necessary. Since there is still much to be learned about thermostabilization mechanisms, SDM approaches often yield disappointing results. Bacillus subtilis subtilisin $\mathrm{E}$ was converted into an equivalent of its thermophilic homolog thermitase through the 
successive application of one round of error-prone PCR, one step of DNA shuffling (to combine the properties of the best variants), and four additional rounds of error-prone (ep) PCR. The evolved enzyme was 15 times more active than subtilisin $\mathrm{E}$ at $37{ }^{\circ} \mathrm{C}$, it showed a $16^{\circ} \mathrm{C}$ increase in $\mathrm{T}_{\mathrm{opt}}$, and its $\mathrm{T}_{\mathrm{m}}$ at $65{ }^{\circ} \mathrm{C}$ was more than 200 times that of subtilisin $\mathrm{E}$ [73]. In another experiment, the thermostability of $B$. subtilis p-nitrobenzyl esterase was enhanced through five cycles of epPCR followed by one step of DNA shuffling [76]. The evolved esterase showed a $14{ }^{\circ} \mathrm{C}$ increase in $\mathrm{T}_{\text {opt }}$ and a $10{ }^{\circ} \mathrm{C}$ increase in $\mathrm{T}_{\mathrm{m}}$, and it was more active than the wild-type enzyme at any temperature.

Using a directed evolution approach, Oshima and coworkers (2001) obtained four variants of a thermophilic 3-isopropylmalate dehydrogenase with enhanced specific activities at low temperatures [77]. Two of these variants exhibited wild-type thermostability, while the other two exhibited decreased thermostability, with an inverse correlation between activity and stability. A similar result was obtained in case of thermostable $S$. cerevisiae 3-isopropylmalate dehydrogenase variants evolved using genetic selection in an extreme thermophile [78]. On the other hand, mutations targeted at areas whose unfolding is limiting in the protein denaturation process can provide extensive stabilization. Good illustrations can be found in the stability studies of Bacillus stearothermophilus thermolysin-like protease. Stabilizing mutations were all located on the surface, around one flexible loop located in the $\beta$-pleated $N$-terminal domain [79-81]. The association of eight mutations in the same area resulted in a 340 -fold kinetic stabilization of $B$. stearothermophilus thermolysin-like protease at $100{ }^{\circ} \mathrm{C}$ and did not affect catalytic activity at $37^{\circ} \mathrm{C}[82]$.

Successes in substituting left-handed helical residues with Gly or Asn, in introducing prolines in surface turns or loops, in introducing non-local surface ion pairs, and in creating disulfide bridges that dock loops to the protein surface are well documented [82-86]. Two types of mutations, Gly to Xaa and Xaa to Pro, can be introduced. In the first case, the newly introduced $\beta$-carbon should not interfere with neighboring atoms. In the second case, the substitution site should have specific dihedral angles $(\varphi$ and $\psi$ ) in the regions -50 to -80 and 120 to 180 or -50 to -70 and -10 to -50 , and the residue preceding the potential proline should also have a specific conformation. In addition, the proline ring should not interfere with neighboring atoms, and the substitution should not eliminate stabilizing non-covalent interactions. The most promising strategies for thermostabilization using SDM should focus on the surface areas, particularly loops and turns, and on creating additional non-local ion pairs. The introduction of disulfide bonds, chemical crosslinks, and salt bridges has been widely used to increase stability, although not all disulfide bonds increase stability [87]. Loops can be made more rigid by decreasing their intrinsic entropy of unfolding. There are now several examples of proteins that have been stabilized by the introduction of numerous mutations with cumulative small stabilizing effects (Table 1) [76,88-91]. However, a clear conclusion to be drawn from others is that very large stability differences in some cases are due to only one or a few point mutations [39,45,46,92-94]. Another method is to anchor the loops to the protein surface, either by non-covalent interactions or using a disulfide bridge. Introducing a disulfide bridge in a semiflexible area of the protein should help compensate for any conformational strain created by the disulfide bridge [80]. 


\subsection{Solvent Stability}

The use of organic solvents as reaction media for biocatalytic reactions has proven to be an extremely useful approach to expand the range and efficiency of the practical applications of biocatalysis [95]. Unfortunately, the majority of naturally available biocatalysts are usually not optimally suited for catalysis in non-aqueous solvents in industrial processes. Polar solvents of practical interest, such as acetone or dimethylformamide (DMF), interact with the enzyme and associated water molecules and drastically reduce catalytic activity [96]. The ability to use enzymes in non-aqueous solvents has increasingly drawn the attention of researchers worldwide to the problems and potential of non-aqueous biocatalysis in chemical transformations that are useful for many industries. There are many potential advantages of enzyme catalysis in non-aqueous solvents, including (1) enhanced solubility of substrates such as lipids and phospholipids; (2) novel chemistry in synthetic applications; (3) altered substrate specificity; (4) easy product recovery; and (5) reduced microbial contamination [95,97]. Despite the many limitations of non-aqueous environments, particularly the poor stability of enzymes in polar organic solvents, research in this area has made tremendous progress in recent years, focusing in particular on the elucidation of enzyme structure and improvement of stability and catalysis in organic solvents, for synthetic applications.

Enzymes may be redesigned to enhance catalysis and stability in non-aqueous solvents by engineering their amino acid sequences, thereby altering their functional properties to adapt the new solvent environment. Many strategies to engineer proteins for non-aqueous environments have been developed [98-102]. Among them, directed evolution and rational design approaches are widely utilized. Directed evolution approaches involving SDM are more efficient when detailed structural information and the molecular basis for the property of interest are poorly understood. Impressive work has been done using an evolutionary approach consisting of multiple steps of random mutagenesis and screening to improve the activity and stability of subtilisin $\mathrm{E}$ in high concentrations of organic solvent [99]. Random mutagenesis by PCR techniques combined with screening resulted in enhanced activity in the presence of dimethylformamide (DMF). The triple mutant $(\mathrm{D} 60 \mathrm{~N}+\mathrm{Q} 103 \mathrm{R}+\mathrm{N} 218 \mathrm{~S})$ is 38 times more active than wild-type subtilisin E in $85 \%$ DMF. Single amino acid substitutions increase the activity and stability of mutant enzyme in mixtures of organic solvents and water, and the effects of these mutations are additive. The N218S substitution is reported to cause improved activity and stability of subtilisin BPN, as well as improved activity and stability of subtilisin E in the presence of DMF. The double mutant Q103R + N218S is 10 times more active than the wild-type enzyme in $20 \%(v / v)$ DMF and twice as stable in $40 \%$ DMF. Similar examples of enzyme stabilization also involve subtilisin $E$ in polar organic solvents (DMF) by rational engineering. The substitution of Asp248 with three amino acids of increasing hydrophobicity, Asn, Ala, and Leu, resulted in stabilized variants with respect to wild type in $80 \%$ DMF. This stabilization was only observed at high concentrations of organic solvent, and not at low organic acid concentrations (40\% DMF). In contrast, the mutant $\mathrm{N} 218 \mathrm{~S}$ stabilizes subtilisin $\mathrm{E}$ at both low (40\%) and high (80\%) concentrations of DMF. The double mutant $(\mathrm{D} 248 \mathrm{~N}+\mathrm{N} 218 \mathrm{~S})$ protein is 3.4 times more stable than the wild type in $80 \%$ DMF [103]. This study provides additional evidence that substitution of surface-charged residues is generally additive and useful for stabilizing enzymes in organic solvent. Using the directed approach, random mutagenesis, recombination, and screening, Song and Rhee 
(2001) obtained three variants of phospholipase A with enhanced stability and activity in organic solvents [104]. Using a similar strategy, Arnold and coworkers (2001) reported a variant of horseradish peroxidase with enhanced stability in the presence of $\mathrm{H}_{2} \mathrm{O}_{2}$, sodium dodecyl sulfate (SDS), and salts [105].

\subsection{Substrate Specificity}

Engineering novel enzyme specificity using a directed evolution approach is of increasing importance to the chemical and pharmaceutical industries. Several recent reports describe significant advances made toward this goal. Using epPCR, followed by saturation mutagenesis and screening, Reetz and coworkers [106,107] considerably modified the enantioselectivity of a Pseudomonas aeruginosa lipase towards 2-methyldecanoate from $E=1.04 \times(2 \%$ enantiomeric excess [ee] $)$ to $E=25 \times(90 \%-93 \%$ ee) (where $E$ is the enantioselective factor). None of the five amino acid substitutions in the best variant was located near the substrate-binding pocket [108]. Using a similar approach, Arnold and coworkers (2000) successfully inverted the enantioselectivity of a hydantoinase from D selectivity ( $40 \%$ ee) to moderate L preference (20\% ee) [7]. An impressive example of switching enzyme substrate specificities can be seen in the DNA shuffling of two highly homologous triazine hydrolases [109]. The two enzymes, AtzA and TriA, are distinguished by nine amino acids, and hydrolyze s-triazines by dechlorination and deamination, respectively, with little overlap in substrate preference. Permutations of the nine amino acid differences by DNA shuffling resulted in a set of variants that hydrolyzed five of eight triazines that were not substrates for either starting enzyme. The E. coli D-2-keto-3-deoxy-6-phosphogluconate (KDPG) aldolase catalyzes a highly specific reversible aldol reaction on D-configurated KDPG substrate. Using directed evolution approach, Wong and coworkers (2000) obtained a variant capable of accepting both D- and L-glyceraldehyde as substrates in a non-phosphorylated form [110]. Notably, all the six substitutions found in the resulting variant were far away from the active site. A double mutant (Lys133Gln/Thr161Lys) of the same enzyme with a considerably altered substrate profile was reported using epPCR and SDM [111]. The directed evolution of oxygenases exhibited similar results [112-115].

\subsection{A Way Forward: Hybrid Approaches}

Over the past decade, advances in DNA technologies and bioinformatics have substantially accelerated the redesign of proteins with novel or desired characteristics. Proteins can be rationally engineered if information about the catalytic mechanism and structure of a protein is known. However, practical experience shows that protein dynamics is complex and it is understood that substitutions distant from the active site can alter the characteristics of a protein [116,117]. Directed evolution would be a more suitable approach for the proteins whose structures and mechanisms are known. However, this method is driven by multiple rounds of selection and screening and each step improves the enzyme. In cases where high-throughput screens are unavailable, a semi-rational method involving site saturation mutagenesis may be applied to identify target residues through computational methods. This way, the library size can be reduced to a manageable size to increase the chance of discovering desired variants. 
Recently, molecular modeling has been employed to predict protein structures and various algorithms are being used to predict secondary and tertiary structures based on amino acid sequence [118-120]. This advancement immensely supports rational design of proteins with unknown structures $[118,120]$. Furthermore, simulation and molecular docking of small molecules to proteins is another field that has advanced tremendously over the years [121,122]. Molecular docking can facilitate understanding of ligand-protein interactions and hence rational designing of proteins for desired properties $[123,124]$.

Assimilation of unnatural amino acids (uAAs) into proteins has opened new possibilities for creating proteins with novel functions and improved properties [125]. Substitution of natural amino acids with a uAA at multiple specific sites in a protein and insertion of uAAs into proteins to expand the genetic code are two different approaches. With such progress, assimilation of uAAs into proteins may soon be a routine practice in the field of protein engineering, and may become a powerful technique for designing novel enzymes to meet the demands of synthetic biology [126].

\section{Immobilization to Upgrade Industrial Enzymes}

Since the first industrial application of immobilized amino acylase in 1967 for the resolution of amino acids, enzyme immobilization technology has attracted increasing attention and considerable progress has been made in recent decades. Enzymes are exploited as catalysts in many industrial, biomedical, and analytical processes. There has been considerable interest in the development of enzyme immobilization techniques because immobilized enzymes have enhanced stability compared to soluble enzymes, and can easily be separated from the reaction. Approaches used for the design of immobilized enzymes have become increasingly more rational and are employed to generate improved catalysts for industrial applications. There are a variety of methods used to immobilize enzymes, the three of the most common being adsorption, entrapment, and crosslinking or covalently binding to a support (Figure 3). Recently, the major focus of enzyme immobilization is the development of robust enzymes that are not only active but also stable and selective in organic solvents. The ideal immobilization procedure for a given enzyme is one that permits a high turnover rate of the enzyme while retaining high catalytic activity over time. Proteins are immobilized either by physical adsorption to the surface of the nanoparticle or by covalent bonding to previously functionalized nanoparticles.

Figure 3. Immobilization of enzyme via different routes.

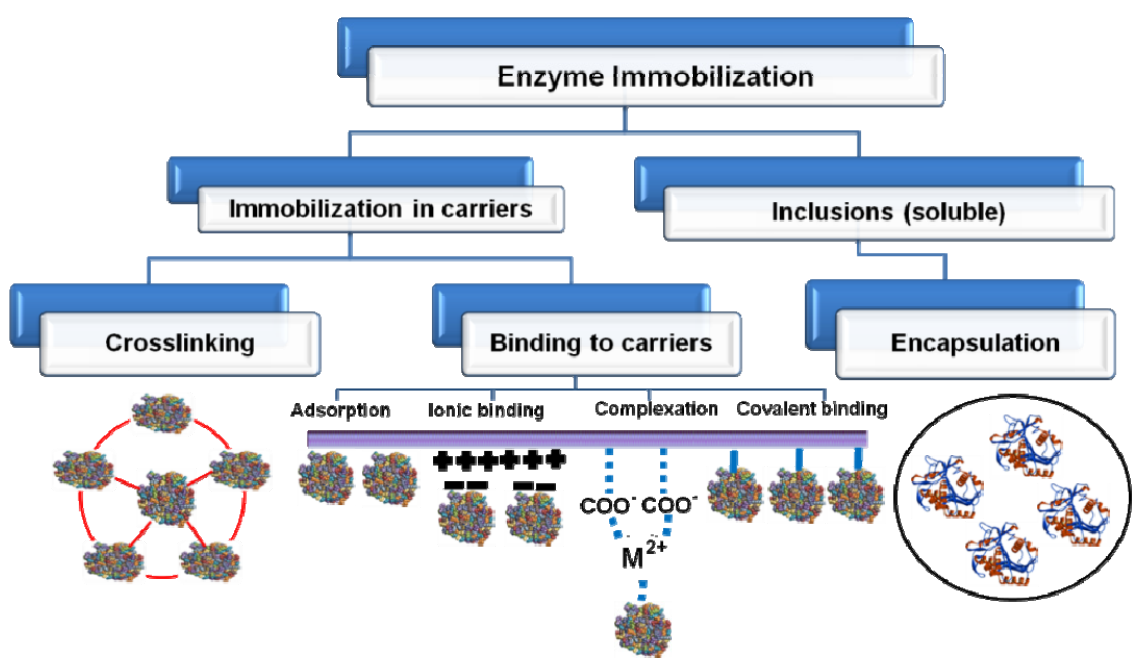




\subsection{Activity}

In the early 1960s Goldstein et al. observed the enhancement of enzyme activity upon immobilization because of the microenvironment effect [127]. In general, enhancement of enzyme activity upon immobilization depends on the microenvironment, partition effect, diffusion effect, conformational change, molecular orientation, conformational flexibility, conformation induction, and binding mode. It has been observed that many immobilized enzymes exhibit higher activity than the corresponding native enzyme. For example, immobilized lipase was 50-fold more active than the native enzyme [128]. In literature, there are few reports of enzymes that exhibit decreased $\mathrm{K}_{\mathrm{m}}$ and increased $\mathrm{V}_{\max }$ upon the formation of crosslinked enzyme aggregates (CLEA) [73,129-131] compared the covalent immobilization and physical adsorption of a cellulase enzyme mixture on plasma immersion ion implantation (PIII)-treated and untreated polystyrene, respectively. Activity on the PIII-treated surface was found to be higher than that on the untreated surface. The activity on the untreated surface may be lower because enzyme aggregates are generally not as active as the same number of unaggregated enzymes. It has been described that immobilized enzymes can be more active than the native enzymes, when the inhibiting effect of the substrate is reduced. For example, the immobilization of invertase from Candida utilis on porous cellulose beads led to decreased substrate inhibition and increased activity [132]. Table 2 includes the examples of enzymes with improved activity via immobilization. Recent advancements in immobilization techniques, particularly in oriented immobilization, have generally resulted in higher activity relative to their randomly immobilized counterparts, because of favorable accessibility or avoidance of active site modification [133]. These methods focus on the improvement of immobilized enzyme properties without compromising activity. In case of trivial immobilization techniques, activity retention was often marginal, requiring laborious screening of immobilization conditions such as enzyme loading, $\mathrm{pH}$, carrier, and binding chemistry [134]. Higher enzyme activity can occasionally be achieved, especially for allosteric enzymes such as lipase. Lipases exist in two different conformations [135,136]: the closed (inactive) form with lids covering the active site, and the open form, where the active site is fully exposed to the reaction medium [137-139], and enhancement of enzyme activity relative to that of the native enzyme can be observed. Conformation-controlled activity was found to be strongly dependent on the nature of the support used immobilization. For example, lipase PS (Pseudomonas cepacia) immobilized on toyonite, celite, glass, and amberlite, exhibited the highest activity on toyonite $\left(37.2 \mu \mathrm{mol} \cdot \mathrm{min}^{-1} \cdot \mathrm{mg}^{-1}\right)$ and the lowest on amberlite $\left(0.4 \mu \mathrm{mol} \cdot \mathrm{min}^{-1} \cdot \mathrm{mg}^{-1}\right)$ [140].

Table 2. Examples of immobilized enzymes with enhanced activity.

\begin{tabular}{cccc}
\hline Enzyme & Applications & Kinetic parameters & Reference \\
\hline \multirow{2}{*}{$\alpha$-Chymotrypsin } & $\begin{array}{c}\text { Proteolysis (cleave Peptide } \\
\text { amide bonds) }\end{array}$ & $\begin{array}{c}\text { Immobilized enzyme: } \mathrm{K}_{\mathrm{m}}=31.7 \mu \mathrm{M}, \mathrm{k}_{\text {cat }}=20.0 \mathrm{~s}^{-1} ; \\
\text { soluble enzyme: } \mathrm{K}_{\mathrm{m}}=47.8 \mu \mathrm{M}, \mathrm{k}_{\mathrm{cat}}=17.8 \mathrm{~s}^{-1}\end{array}$ \\
\hline \multirow{3}{*}{-glucosidase } & Immobilized enzyme: $\mathrm{K}_{\mathrm{m}}=10.8 \mathrm{mM}$, \\
& Lignocellulose hydrolysis & $\mathrm{V}_{\max }=2430 \mu \mathrm{mol} \cdot \mathrm{min}^{-1} \cdot \mathrm{mg}^{-1} ;$ \\
& soluble enzyme: $\mathrm{K}_{\mathrm{m}}=1.1 \mathrm{mM}$, \\
\hline
\end{tabular}


Table 2. Cont.

\begin{tabular}{|c|c|c|c|}
\hline Enzyme & Applications & Kinetic parameters & Reference \\
\hline Glucose oxidase & $\begin{array}{l}\text { Estimation of glucose level } \\
\text { up to } 300 \mathrm{mg} \cdot \mathrm{mL}^{-1}\end{array}$ & $\begin{array}{l}\text { Immobilized enzyme: } \mathrm{K}_{\mathrm{m}}=3.74 \mathrm{mM} \\
\text { soluble enzyme }=5.85 \mathrm{mM}\end{array}$ & [143] \\
\hline Diastase & Starch hydrolysis & $\begin{array}{l}\text { Immobilized enzyme: } \mathrm{K}_{\mathrm{m}}=8414 \mathrm{mM} \\
\qquad \mathrm{V}_{\max }=4.92 \mu \mathrm{mol} \mathrm{min}^{-1} \mathrm{mg}^{-1} \\
\text { soluble enzyme: } \mathrm{K}_{\mathrm{m}}=10,176 \mathrm{mM} \\
\mathrm{V}_{\max }=2.71 \mu \mathrm{mol} \mathrm{min} \mathrm{mg}^{-1}\end{array}$ & [144] \\
\hline$\beta$-galactosidase & GOS synthesis & $\begin{array}{c}\text { Immobilized enzyme: } \mathrm{k}_{1}=1.41 \mathrm{~h}^{-1} \\
\text { soluble enzyme: } \mathrm{k}_{1}=1.16 \mathrm{~h}^{-1}\end{array}$ & {$[145]$} \\
\hline Keratinase & Synthesis of keratin & $\begin{array}{l}\text { Immobilized enzyme: specific activity }=129.0 \mathrm{U} \cdot \mathrm{mg}^{-1} \\
\text { soluble enzyme: specific activity }=37 \mathrm{U} \cdot \mathrm{mg}^{-1}\end{array}$ & {$[146]$} \\
\hline Horseradish peroxidase & & $\begin{array}{l}\text { Immobilized enzyme: } \mathrm{K}_{\mathrm{m}}=0.8 \mathrm{mM} \\
\mathrm{V}_{\max }=0.72 \mu \mathrm{mol} \mathrm{min} \mathrm{mg}^{-1} \\
\text { soluble enzyme: } \mathrm{K}_{\mathrm{m}}=0.43 \mathrm{mM} \\
\mathrm{V}_{\max }=0.35 \mu \mathrm{mol} \mathrm{min} \mathrm{mg}^{-1}\end{array}$ & [147] \\
\hline Glucose oxidase & Estimation of glucose level & $\begin{array}{c}\text { Immobilized enzyme: } \mathrm{K}_{\mathrm{m}}=2.7 \mathrm{mM} \\
\qquad \mathrm{V}_{\max }=28.6 \mathrm{U} \cdot \mu \mathrm{g}^{-1} \\
\text { soluble enzyme: } \mathrm{K}_{\mathrm{m}}=9 \mathrm{mM} \\
\mathrm{V}_{\max }=6.2 \mu \mathrm{mol} \cdot \mathrm{min}^{-1} \mathrm{mg}^{-1}\end{array}$ & [148] \\
\hline $\begin{array}{l}\beta-1,4 \text {-glucosidase } \\
\text { (Agaricus arvensis) }\end{array}$ & Lignocellulose hydrolysis & 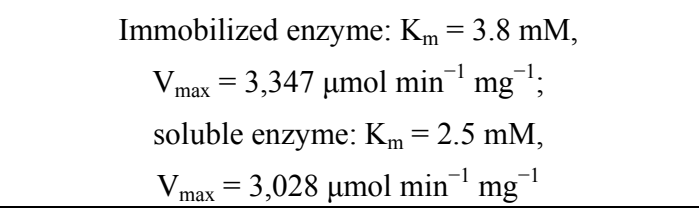 & [149] \\
\hline $\begin{array}{l}\text { L-arabinose isomerase } \\
\quad(\text { B. licheniformis })\end{array}$ & & $\begin{array}{c}\text { Immobilized enzyme: } \mathrm{K}_{\mathrm{m}}=352 \mathrm{mM} \\
\mathrm{V}_{\max }=326 \mu \mathrm{mol} \mathrm{min} \mathrm{mg}^{-1} \\
\text { soluble enzyme: } \mathrm{K}_{\mathrm{m}}=369 \mathrm{mM} \\
\mathrm{V}_{\max }=232 \mu \mathrm{mol} \mathrm{min} \mathrm{mg}^{-1}\end{array}$ & {$[150]$} \\
\hline Diastase $\alpha$-amylase & Hydrolyzing soluble starch & 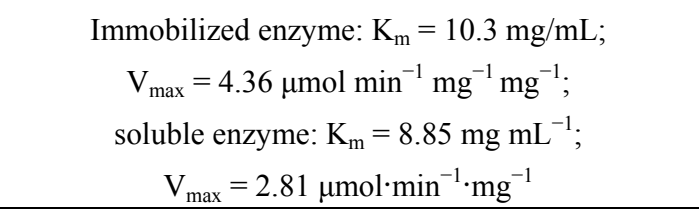 & {$[151]$} \\
\hline Cellobiase & Bioethanol production & 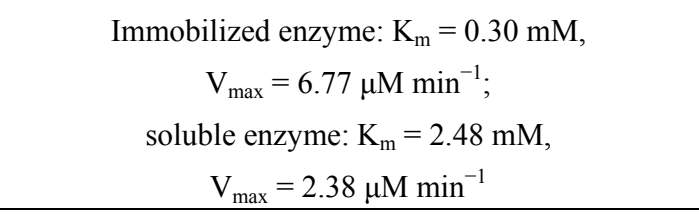 & {$[152]$} \\
\hline Laccase & $\begin{array}{c}\text { Bioremediation } \\
\text { of environmental } \\
\text { pollutants }\end{array}$ & 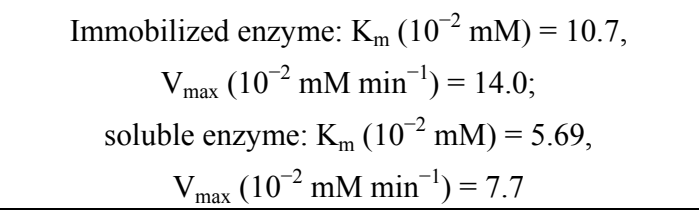 & [153] \\
\hline Keratinase & Synthesis of keratin & $\begin{array}{l}\text { Immobilized enzyme: specific activity }=129 \mathrm{U} \mathrm{mg}^{-1} \text {; } \\
\text { soluble enzyme: specific activity }=37 \mathrm{U} \mathrm{mg}^{-1}\end{array}$ & {$[146]$} \\
\hline $\begin{array}{l}\text { Raw starch digesting } \\
\text { amylases }\end{array}$ & Starch hydrolysis & $\begin{array}{c}\text { Immobilized enzyme: } \mathrm{K}_{\mathrm{m}}\left(10^{-1}\right)=3.8 \mathrm{mg} \mathrm{mL}^{-1} \\
\mathrm{~V}_{\max }=27.3 \mathrm{U} \cdot \mathrm{mg}^{-1} \\
\text { soluble enzyme: } \mathrm{K}_{\mathrm{m}}\left(10^{-1}\right)=3.5 \mathrm{mg} \mathrm{mL}^{-1} \\
\mathrm{~V}_{\max }=23.8 \mathrm{U} \cdot \mathrm{mg}^{-1}\end{array}$ & [154] \\
\hline
\end{tabular}


Table 2. Cont.

\begin{tabular}{|c|c|c|c|}
\hline Enzyme & Applications & Kinetic parameters & Reference \\
\hline Aldolase & & $\begin{array}{c}\text { Immobilized enzyme: } \mathrm{K}_{\mathrm{m}}=0.10 \mathrm{mM} \\
\mathrm{k}_{\mathrm{cat}} / \mathrm{K}_{\mathrm{m}}=584 \mathrm{~min}^{-1} \cdot \mathrm{mM}^{-1} \\
\text { soluble enzyme } \mathrm{K}_{\mathrm{m}}=0.12 \mathrm{mM} \\
\mathrm{k}_{\mathrm{cat}} / \mathrm{K}_{\mathrm{m}}=540 \mathrm{~min}^{-1} \cdot \mathrm{mM}^{-1}\end{array}$ & {$[155]$} \\
\hline 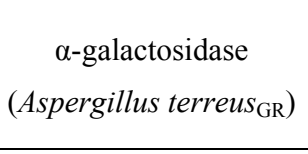 & Animal feed & $\begin{array}{c}\text { Immobilized enzyme: } \mathrm{K}_{\mathrm{m}}=1.40 \mathrm{mM} \\
\mathrm{V}_{\max }=20.16 \mathrm{U} \mathrm{mL}^{-1} \\
\text { soluble enzyme: } \mathrm{K}_{\mathrm{m}}=4.2 \mathrm{mM}, \mathrm{V}_{\max }=16.33 \mathrm{U} \cdot \mathrm{mL}^{-1}\end{array}$ & {$[156]$} \\
\hline Laccase & $\begin{array}{l}\text { Textile wastewater } \\
\text { treatment }\end{array}$ & $\begin{array}{c}\text { Immobilized enzyme: } \mathrm{K}_{\mathrm{m}}=0.0717 \mathrm{mM} \\
\mathrm{V}_{\max }=0.247 \mathrm{mM} \cdot \mathrm{min}^{-1} \\
\text { soluble enzyme: } \mathrm{K}_{\mathrm{m}}=0.0044 \mathrm{mM} \\
\mathrm{V}_{\max }=0.024 \mathrm{mM} \cdot \mathrm{min}^{-1}\end{array}$ & {$[157]$} \\
\hline Papain & $\begin{array}{l}\text { Food, pharmaceutical, } \\
\text { leather, cosmetic, and } \\
\text { textile industries }\end{array}$ & $\begin{array}{c}\text { Immobilized enzyme: } \mathrm{K}_{\mathrm{m}}=0.308 \times 10^{5} \mathrm{~g} \cdot \mathrm{mL}^{-1} \\
\qquad \mathrm{~V}_{\max }=5.4 \mathrm{~g} \mathrm{~mL} \mathrm{~s}^{-1} \mathrm{~s}^{-1} \\
\text { soluble enzyme: } \mathrm{K}_{\mathrm{m}}=0.236 \times 10^{5} \mathrm{~g} \cdot \mathrm{mL}^{-1} \\
\mathrm{~V}_{\max }=4.08 \mathrm{~g} \cdot \mathrm{mL}^{-1} \cdot \mathrm{s}^{-1}\end{array}$ & {$[158]$} \\
\hline
\end{tabular}

An enzyme immobilized in an oriented manner using a covalent procedure preserves its functionality and leads to the assemblage of a homogeneous layer. It was demonstrated that the lipase from Mucor risopus immobilized in organic solvent was more active in organic solvent whereas the same immobilized in an aqueous medium had almost no activity in organic solvents. It might be that the position of binding of the enzymes to the carrier in organic solvents is different from when immobilization is performed in an aqueous medium [159]. Recently, analysis of cytochrome c reductase assay revealed that oriented enzyme samples resulted in about a three-fold higher activity in solution than randomly bound samples because of favorable accessibility [160]. Orderly oriented enzyme molecules generally have higher activity or stability relative to their randomly immobilized counterpart [133].

When the enzyme is covalently immobilized in porous materials using the conventional protocol, diffusion limitations of the enzyme inside the carriers and slow binding reactions between the enzyme and activated carrier groups slow down the covalent immobilization of the enzyme [155]. Activity retention by carrier-bound immobilized enzymes is usually approximately 50\% [161]. At high enzyme loading, especially, diffusion limitation might occur as a result of the unequal distribution of the enzyme within a porous carrier, leading to a reduction of pore volume available to the substrate and product diffusion. Bezbradica et al. (2009) reported the specific activity of microwave-assisted immobilization of lipase from Candida rugosa on Eupergit C250L was higher because of higher diffusion rate [162]. Microwave irradiation technology has been reported by several researchers to overcome the diffusion limitation. For instance, penicillin acylase from Bacillus megaterium was covalently immobilized on mesocellular silica foams [155].

It is a common belief that conformational flexibility provides a protein structure with the essential mechanism for carrying enzymatic reactions. The effect of conformational flexibility on the enzyme activity was initially justified by the observation that enzyme immobilized on a carrier via a suitable spacer often resulted in better retention of activity than the enzyme immobilized without a spacer [163-166]. Bigdeli et al. (2008) reported the retention of conformational flexibility of 
glutamate dehydrogenase, used as a model allosteric protein, upon its immobilization on self-assembled monolayers-modified gold [167].

Activity of immobilized enzyme is often influenced by binding mode. The effect of binding mode may be reflected by the number of bonds formed between the carrier and the enzyme molecules, the position of the bonds and the nature of the bonds. Immobilization of $\beta$-galactosidase from E. coli and Kluyveromyces lactis on thiolsulphinate-agarose and glutaraldehyde-agarose clearly demonstrates the relation between the number of bonds formed between the enzyme and the carrier and enzyme activity [168]. These two enzymes are richer in the lysine residues resulting in more bonds formation with glutaraldehyde-agarose and less retention of activity. Interestingly, $\alpha$-amylase immobilized on thionyl chloride $\left(\mathrm{SOCl}_{2}\right)$ and carbodiimide (CDI) activated poly (Me methacrylate-acrylic acid) microspheres retained $67.5 \%$ and $80.4 \%$ of activity, respectively [169].

Conformational changes of the enzyme induced by immobilization usually decrease the affinity to the substrate (increase of $\mathrm{K}_{\mathrm{m}}$ ). Furthermore, a partial inactivation of all, or the complete inactivation of a part of the enzyme molecules may occur (decrease of $\mathrm{V}_{\max }$ ). Hanefeld et al. (2008) reported that the difference in kinetics between lipases immobilized on different supports was ascribable to conformational changes induced upon enzyme-polymer interaction [170]. A similar observation had been reported for immobilized invertase on white and black lahar (volcanic mudflow) by the silane-glutarldehyde method [171]. Immobilization brought about an increase in the $\mathrm{K}_{\mathrm{m}}$ but a decrease in the $\mathrm{V}_{\max }$ and these changes were correlated to immobilization induced conformational changes in the enzyme [172].

\subsection{Thermal Stability}

Enormous efforts have made by several research groups to enhance the stability of enzymes with the help of immobilization techniques [170], for use in industrial processes, in which the cost-contribution of the immobilized enzyme is often the indicator of process viability [173]. Random immobilization may not always applicable to improve enzyme rigidity; in some cases, the enzyme stability may even be reduced upon immobilization [174]. During random immobilization, the support may establish undesirable interactions with the enzyme resulting in the destabilization of the enzyme structure. Many useful strategies have been developed for enzyme stabilization by immobilization, such as crosslinking, multipoint attachment, and covalent and non-covalent immobilization. The stability of the immobilized enzyme depends on various factors such as the interaction with the support, binding position, the number of the bonds, conformational freedom, microenvironment, structure of the support, properties of the spacer (charged or neutral, hydrophilic or hydrophobic, size), and immobilization conditions. However, the enhanced stability resulting from immobilization is often ascribed to the intrinsic features of individual immobilization processes. The stability of immobilized enzyme is often determined by an individual stabilization factor or the cumulative effect of several factors. The same immobilization method leads to different stabilities depending on the selected support and immobilization conditions [134]. For example, lipase from Candida rugosa was found to be more stable when entrapped in alginate gel than when covalently bound on Eupergit $\mathrm{C}$ or encapsulated in a sol-gel matrix [175]. Another striking example is that immobilized glucoamylase entrapped in polyacrylamide gels was found to be more stable than that covalently bound to SP-Sephadex C-50 [176]. Enzyme stabilization by immobilization is currently no longer an exception, 
because of our increasing understanding of immobilization processes. Thermophilic and hyperthermophilic enzymes are further stabilized by immobilization [177-180], suggesting the additive nature of enzyme stabilization by immobilization.

Physical adsorption and covalent binding both reduce or avoid enzyme leaching, but binding to a planar surface can lead to decreased stability or even protein denaturation. Crosslinking of enzymes usually increases their stability at the expense of decreased activity. Microencapsulation into micelles or micellar polymers offers the highest potential to significantly increase enzyme lifetime and stop enzyme leaching, although mass transfer problems may occur. The binding of an enzyme to an external organic or inorganic support introduces additional covalent or non-covalent interactions. This additional interaction decreases the structural flexibility of the enzyme and provides rigidity to the immobilized enzyme, which in turn decreases its liability for denaturation. Figure 4 illustrates the different strategies used to immobilize enzymes at support surfaces to enhance stability. Multiple-point attachment (or crosslinking) for stabilization of carrier-bound immobilized enzyme was introduced in the beginning of the 1970s and further explored to design stable carrier-bound immobilized enzymes. The extent of stabilization of immobilized enzyme by multipoint attachment depends on the number of bonds between the enzyme and the support. The characteristics of the support, reactive groups, and immobilization conditions need to be carefully selected to involve the maximum number of enzyme groups in the immobilization. In fact, it has been possible to correlate the enzyme stabilization reached with the number of enzyme-support linkages [181].

Figure 4. Enzyme stabilization by immobilization introduces additional covalent and non-covalent forces to an external matrix. (A) Non-covalent physical adsorption of an enzyme on the nanoparticle; (B) covalent binding of an enzyme to the nanoparticle (multipoint attachment); (C) covalent crosslinking of enzymes; and (D) microencapsulation of an enzyme by a micelle.

A

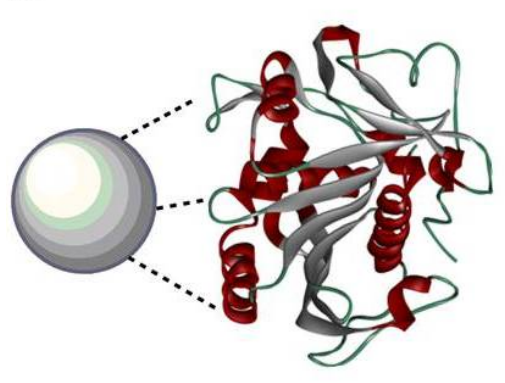

C

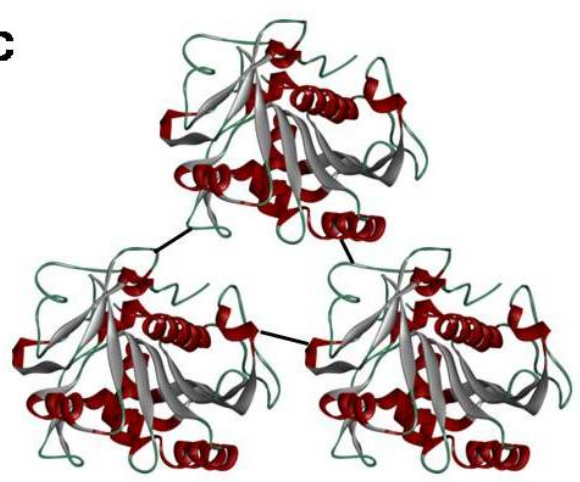

B

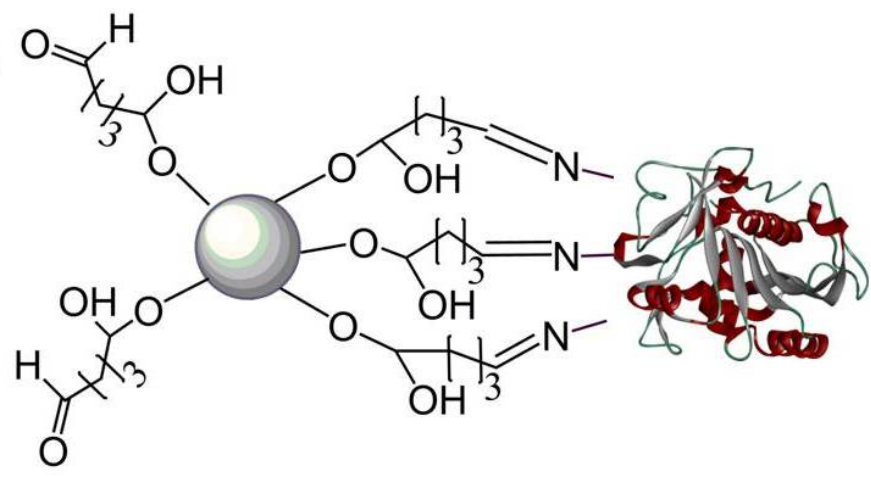

D

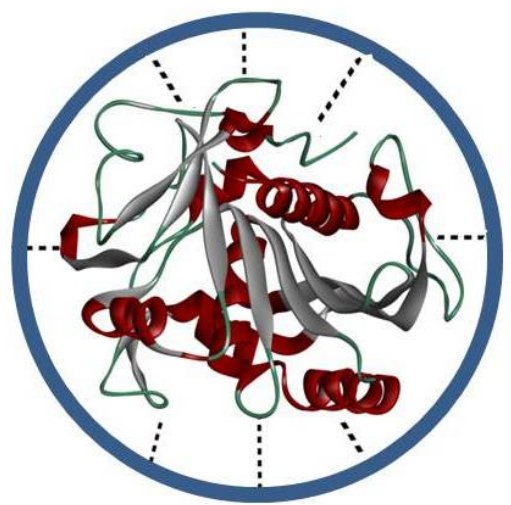


Covalent binding of an enzyme to a carrier has the advantage that the enzyme is tightly fixed. This is due to the fact that the formation of multiple covalent bonds between the enzyme and the carrier reduces conformational flexibility and thermal vibrations, thus preventing protein unfolding and denaturation $[149,170,182-184]$. The amino groups of the enzyme can initiate nucleophilic attack on, for instance, an epoxide or an aldehyde on the support, forming covalent bonds. As in the case of lipase immobilization, shorter spacers confer higher thermal stability, because they restrict enzyme mobility and prevent unfolding. For example, immobilization of $\beta$-1,4-glucosidase (BGL) from Agaricus arvensis on silicon oxide nanoparticles by covalent binding confers a 288 -fold enhancement in half-life over free BGL at $65{ }^{\circ} \mathrm{C}$ [149]. $\alpha$-Amylase was covalently immobilized onto phthaloyl chloride-containing amino group-functionalized glass beads. The immobilized $\alpha$-amylase exhibited better thermostability than free amylase $[185,186]$. The covalent immobilization of cellulase and invertase has been shown to improve stability with respect to $\mathrm{pH}$, temperature, and storage, compared to free enzyme in solution $[131,187]$.

Table 3 shows some of the results obtained after immobilizing many different proteins $[178,181,188,189]$. The stabilization factors are in many cases extremely high (1000- to 10,000 -fold) with activity recoveries usually over $60 \%$. Moreover, it should be noted that any other technique employed to obtain a stable enzyme (protein engineering, screening, etc.) should be compatible with the stabilization of the enzyme by multipoint covalent attachment, because immobilization will be almost a necessary step for the preparation of an industrial biocatalyst. Thus, enzymes from extremophiles have also been stabilized by multipoint covalent attachment [178,189-191].

Table 3. Examples of enzyme stabilization by immobilization.

\begin{tabular}{cccc}
\hline Enzyme & $\begin{array}{c}\text { Recovered } \\
\text { activity (\%) }\end{array}$ & $\begin{array}{c}\text { Stabilization } \\
\text { factor }^{\text {a }}\end{array}$ & Reference \\
\hline Lipase (C. rugosa) & 50 & $150^{\text {a }}$ & {$[192]$} \\
Penicillin G acylase (E. coli) & 70 & $8000^{\text {a }}$ & {$[193]$} \\
Chymotrypsin & 70 & $60,000^{\text {a }}$ & {$[194]$} \\
Penicillin G acylase (K. citrophila) & 70 & $7000^{\text {a }}$ & {$[195]$} \\
Esterase (B. stearothermophilus) & 70 & $1000^{\text {a }}$ & {$[178]$} \\
Thermolysin (B. thermoproteolyticus) & 100 & $100^{\text {a }}$ & {$[191]$} \\
Cholesterol oxidase & nd & $2.5\left(50{ }^{\circ} \mathrm{C}\right)$ & {$[196]$} \\
Alcalase & 54 & 500 & {$[197]$} \\
Urokinase & 80 & 10 & {$[198]$} \\
Invertase & nd & $2\left(70^{\circ} \mathrm{C}\right)$ & {$[199]$} \\
a-Amylase (B. licheniformis) & nd & $2\left(70^{\circ} \mathrm{C}\right)$ & {$[200]$} \\
Dextransucrase (L. mesenteriodes) & nd & $40\left(30^{\circ} \mathrm{C}\right)$ & {$[201]$} \\
Formate dehydrogenase (Pseudomonas sp. 101) & 50 & $>5000^{\mathrm{a}}$ & {$[188]$} \\
Alcohol dehydrogenase (H. Liver) & 90 & $>3000$ & {$[202]$} \\
Cyclodextrin glycosyltransferase (B. circulans) & 70 & $>100$ & {$[203]$} \\
Formate dehydrogenase (C. boidini) & 15 & $150^{\mathrm{a}}$ & {$[204]$} \\
Laccase (Rhus vernicifera) & 80 & $6.4\left(65^{\circ} \mathrm{C}\right)$ & {$[205]$} \\
\hline
\end{tabular}


Table 3. Cont.

\begin{tabular}{|c|c|c|c|}
\hline Enzyme & $\begin{array}{c}\text { Recovered } \\
\text { activity (\%) }\end{array}$ & $\begin{array}{c}\text { Stabilization } \\
\text { factor }^{\mathrm{a}}\end{array}$ & Reference \\
\hline Xylitol dehydrogenase (Rhizobium etli) & 92 & $2.2\left(60^{\circ} \mathrm{C}\right)$ & [206] \\
\hline Laccase (Trametes versicolor) & 69 & $2.5\left(45^{\circ} \mathrm{C}\right)$ & [207] \\
\hline$\beta$-1,4-glucosidase (Agaricus arvensis) & 158 & $288\left(65^{\circ} \mathrm{C}\right)$ & [149] \\
\hline Cellulase (Trichoderma viride) & nd & $2\left(55^{\circ} \mathrm{C}\right)$ & [208] \\
\hline$\beta$-Galactosidase & nd & $17\left(55^{\circ} \mathrm{C}\right)$ & [209] \\
\hline Lipase G (Penicillium camembertii) & nd & $1.7\left(40^{\circ} \mathrm{C}\right)$ & [210] \\
\hline Phytases (Aspergillus niger) & 66 & $7\left(60^{\circ} \mathrm{C}\right)$ & [211] \\
\hline Phytases (Escherichia coli) & 74 & $9.7\left(60^{\circ} \mathrm{C}\right)$ & [211] \\
\hline L-arabinose isomerase (Bacillus licheniformis) & 145 & $137.5\left(50^{\circ} \mathrm{C}\right)$ & [150] \\
\hline Protease (Aspergillus oryzea) & 85 & $3.5\left(70{ }^{\circ} \mathrm{C}\right)$ & [212] \\
\hline Papain & 40 & $4.2\left(70^{\circ} \mathrm{C}\right)$ & [213] \\
\hline Cellobiase & 284 & $1.2\left(60^{\circ} \mathrm{C}\right)$ & [152] \\
\hline Invertase & NR & $3.5\left(55^{\circ} \mathrm{C}\right)$ & [214] \\
\hline$\alpha$-Amylase (Bacillus amyloliquifaciens TSWK1-1) & 91 & $3.75\left(60^{\circ} \mathrm{C}\right)$ & [215] \\
\hline$\alpha$-Galactosidase (Aspergillus terreus ${ }_{\mathrm{GR}}$ ) & 74 & $3.5\left(65^{\circ} \mathrm{C}\right)$ & [156] \\
\hline
\end{tabular}

${ }^{\text {a }}$ Compared with one-point immobilized enzymes.

\subsection{Solvent Stability}

Enzymes tend to form aggregates in organic solvents and hence tend to be poorly accessible for the substrate. The effects of organic solvents on enzymes are usually detrimental and their adverse influences can be mitigated by using immobilized enzyme preparations. Immobilization of enzymes has improved their activity in organic solvents 100-fold [216,217]. Mesoporous materials have attracted much attention due to their porous structure, which may permit full dispersal of enzyme molecules without the possibility of interacting with any external interface. Moreover, the immobilized enzyme molecules will not be in contact with any external hydrophobic interface [218,219] and cannot inactivate the enzymes immobilized on a porous solid [188]. In the presence of an organic solvent, the immobilized enzymes may be in contact with molecules that are soluble in the aqueous phase, but not with the molecules in the organic phase. Thus, any technique that immobilizes the enzyme inside a porous solid provides operational stability to the enzyme, even without affecting the native structure of the enzyme. However, this stabilization is not universally associated with immobilization. The activity of immobilized enzymes is also influenced by the properties of the support, e.g., the aquaphilicity [220]. For example, laccase immobilized on silica gel was 20-fold and 72-fold more active in diethyl ether than in ethyl acetate and methylene chloride, respectively [221]. Furthermore, overall, the Nylon 66 membrane support resulted in the best laccase activity in these three solvents. This shows that the effect of the support matrix on enzyme activity can be more pronounced than solvent-dependent differences. Wang et al. reported the activities of different enzymes immobilized in the molecular hydrogels and their superactivity in toluene relative to unconfined enzymes in water. $\alpha$-glucosidase from baker's yeast in organic cosolvents was stabilized by an order of magnitude by immobilization onto macroporous poly(glycidyl methacrylate-co-ethylene glycol dimethacrylate) [222]. Lipase immobilized on Amberlite XAD-7 maintained 100\% of its synthetic activity even after 30 hours of 
incubation in n-hexane, heptanes, or isooctane. In contrast, free lipase showed too low or no hydrolytic activity after incubation in organic solvents [223].

\subsection{Selectivity}

The selectivity of enzymes is nowadays becoming a powerful asset of enzyme-mediated asymmetric synthesis, because of the increasing need of the pharmaceutical industry for optically pure intermediates [163]. The enzyme shows high specificity towards the natural substrate, but this value may be significantly reduced when the enzyme is intended to be used against compounds that are unlike their natural substrate. The selectivity of enzymes includes substrate selectivity, stereoselectivity, and regioselectivity [224]. Modulation of enzyme substrate selectivity has been achieved by selecting the immobilization technique [174]. Candida rugosa lipase (CRL) is an important industrial lipase; due to its wide substrate specificity it is successfully utilized in a variety of hydrolysis and esterification reactions. The synthesis of several pharmaceuticals is made possible due to its high stereoselectivity and regioselectivity [186,225]. Genetic engineering has been extensively used to alter enzyme selectivity [226]. However, there are also many interesting examples in which enzyme selectivity has been altered by a variety of immobilization techniques such as covalent bonding, entrapment, and simple adsorption. On many occasions, it has been found that a non-selective enzyme such as chloroperoxidase is transformed into a stereoselective enzyme after immobilization an $S$-selective CRL has also been converted to an $R$-selective CRL by covalent immobilization [227].

Selectivity that can be influenced by the immobilization technique can be classified into two major groups: support-controlled (pore size-controlled and diffusion-controlled) and conformation-controlled (microenvironment-controlled and active site-controlled), on the basis of the effect of the source. For example, the product pattern of controlled pore glass (CPG)-immobilized subtilisin-catalyzed digestion of proteins can be affected by the pore size of the carrier used [228]. Urokinase covalently immobilized on glyoxal agarose exhibited changed selectivity towards glutathione $S$-transferase [198,229]. $\alpha$-Amylase immobilized on silica [230] or covalently bound to CNBr-activated carboxymethyl cellulose [231] afforded products whose composition differed from that obtained with the native enzyme. This was largely attributed to the fact that the size of the pores where the enzyme molecules are located determines the accessibility of the substrates, depending on their size. Diffusion-controlled enantioselectivity was reported after a study of the enantioselectivity of the lipase CaL-B in transesterification in organic solvents [232]. A relevant example worth mentioning is that simple adsorption of CRL on Celite not only enhanced its stability in acetaldehyde but also enhanced its enantioselectivity up to three-fold [233].

Immobilization may produce some distortion in the enzyme structure, particularly in the active site region. The immobilization of a protein via different regions may therefore confer different rigidities and distort the enzyme in very different ways; it may be even possible to generate different microenvironments around the enzyme with very different physical properties [174]. The enantiopreference of lipases were successfully modulated using the above strategy [227,234-238]. It has been reported that the same lipase immobilized on different supports may exhibit very different enantioselectivities (in some cases even an inversion) in the same experimental conditions. A detailed analysis of the enantiopreferences of lipases has been reported by Mateo et al. (2007) [174]. In some 
cases, a change in experimental conditions can cause opposing effects on different immobilized preparations [227,234,237]. However, these enantioselectivity modulations are examples of random immobilization, which produces alteration even if it is not desirable. The use of this strategy may sometimes result in properties that are less desirable than those of the free enzyme. Therefore, directed immobilization is a powerful tool to modulate enzyme properties.

Directed immobilization involves the selection of the point of attachment through specific interactions between functional groups on the support and the enzyme, based on detailed structural information of the enzyme and the structure of the support. The properties of the immobilized enzyme depend on the modification (the immobilization conditions), the nature of the modifier (nature of support), and the nature of the enzyme (source, purity, and strain). Lipases are the best example and have been most extensively studied for the modulation of enantioselectivity by immobilization. In another successful example reported by Cabrera et al. (2009), the stereoselectivity of CaL-B lipase for hydrolysis of racemic 2-O-butyryl-2-phenylacetic acid changed both quantitatively (\% ee) and qualitatively ( $R$ or $S$ enantiomer product) when bound hydrophobically to different supports, shifting from $99 \%$ ee $(S)$ on Lewatit to $95 \%(R)$ on octyl agarose [239]. Yilmaz et al. (2011) reported that sporopollenin-based encapsulated lipase in particular had higher conversion and enantioselectivity compared to sol-gel free lipase [186]. These results reveal that sol-gel encapsulated lipase has high enantioselectivity $(E)$ and conversion (x) compared with covalently immobilized lipase (Candida rugosa lipase). In this study, excellent enantioselectivity $(E>400)$ was noticed for most lipase preparations ( $E=166$ for the free enzyme) with an ee value of $98 \%$ for $S$-Naproxen. Recently (Sahin et al., 2009), CRL was encapsulated by polycondensation of tetraethoxysilane and octyltriethoxysilane in the presence of the compounds calix[n]arene, calix[n]-NH, and calix[n]-COOH $(n=4,6$, and 8) [240]. For encapsulated CRL-catalyzed hydrolysis of racemic Naproxen methyl ester in aqueous phase/isooctane biphasic medium, the temperature, $\mathrm{pH}$ of the aqueous phase, and calix[n]arene-based additives were found to have important effects on the conversion and enantioselectivity. Wang et al. (2008) found that the esterase of Kelbsiella oxytoca provided a much higher enantiomeric ratio in the hydrolysis of $(R, S)$-ethyl mandelate when the enzyme was immobilized on Eupergit C 250 L [241].

With regard to the improvement of enzyme selectivity, there are many exciting examples, as noted above, of immobilized enzymes for which selectivity, e.g., reaction selectivity, substrate selectivity, stereoselectivity, or chemical selectivity, can be affected by the immobilization procedure [242,243], perhaps combined with reaction medium engineering [237]; however, the improvement of enzyme selectivity by immobilization is fundamentally still a new endeavor, lacking guidelines that can be used to guide practical experiments. Nevertheless, with the increasing understanding of the relationship between enzyme selectivity and the structural changes resulting from genetic engineering or other chemical modifications, increasing interest in the improvement of enzyme selectivity by immobilization can be expected in the near future.

\subsection{Substrate Tolerance}

Inhibition of enzymes during the reaction by substrates, reaction products, or components of the bulk medium is major issue in the application of biocatalysts in industrial processes. Depending on the type of inhibition, specific inhibitors tend to interact with the enzyme structure at specific positions to 
produce the inhibition. Thus, immobilization may reduce inhibition based on the type of inhibition mechanism in different situations. First, when the inhibitor acts allosterically, interacting with the protein in a place different from the active center, the allosteric site of enzyme may be blocked during the course of the immobilization procedure, significantly reducing the inhibition caused by this mechanism. Second, when the inhibitor interacts with the active site of the protein, immobilization may slightly distort the enzyme active site, and in some cases a higher distortion of the enzyme may be achieved in the inhibitor binding site than in the substrate binding site. This is more likely if the substrate is larger than the inhibitor and interacts with a larger number of groups in the enzyme.

A lactase from Kluyveromyces lactis shows competitive inhibition by galactose $(\chi=45 \mathrm{mM})$ and non-competitive by glucose $(\chi=750 \mathrm{mM})$ [244]; upon immobilization of this lactase, the inhibition constant for galactose was improved from $45 \mathrm{mM}$ to $40 \mathrm{M}$. Similar enhancement was obtained in the case of lactase from Thermus sp. by galactose $(\chi=3.1 \mathrm{mM})$ and non-competitive inhibition by glucose $(\chi$ was $50 \mathrm{mM})$ [245]. The immobilization of lactase on different supports permitted the screening of the preparation, where the $\chi$ by glucose was increased by a two-fold factor, while the competitive $\chi$ by galactose was increased by a four-fold factor [245]. Another example of reduced substrate inhibition and increased activity upon immobilization on porous cellulose beads has been reported for invertase from Candida utilis [132].

\subsection{Multi-Step Reactions}

Co-immobilized multi-enzymatic systems are increasingly driven by economic and environmental constraints that also permit multi-enzyme reactions through artificial enzymatic cascade processes through compartmentalization of the individual catalysts [217]. For example, Brazeau et al. (2008) have developed a multi-enzyme pathway, immobilized on Eupergit $\mathrm{C}$, for the synthesis of the monatin [246]. Co-immobilization of three cellulases on Au-doped magnetic silica nanoparticles for the degradation of cellulose has been reported by Cho et al. [247]. The simultaneous co-immobilized three cystein-tagged cellulases, including endo-glucanase (EGIVCBDII), exo-glucanase (CBHII), and $\beta$-glucosidase (BglB) co-immobilized on AuNP (gold nanoparticles) and Au-MSNP (gold-doped magnetic silica nanoparticles) was successfully demonstrated for the production of cellobiose and glucose. Co-immobilization of coupled enzyme systems can enhance activity and stability [248] such as where nitrobenzene nitroreductase and glucose-6-phosphate dehydrogenase were co-encapsulated in silica particles, wherein the G6PD allowed regeneration of NADPH. St. Clair et al. (2000) also demonstrated that the CLEC could also retain cofactors for redox reactions [249]. As such, co-immobilization provides benefits that span numerous biotechnological applications, from biosensing of molecules to cofactor recycling and to combination of multiple biocatalysts for the synthesis of valuable products.

Selective compartmentalization of enzymes during immobilization could provide advantages. An interesting example of multi-enzyme compartmentalization was reported by Dongen et al. [250]. The co-polymer of isocyanopeptides and styrene was used to form porous polymersomes immobilized with horseradish peroxidize, CaL-B and glucose oxidase anchored to the membrane surface, bilayer membrane, and in the polymersome lumen, respectively. The three enzymes were able to perform a three sequential steps reaction using glucose acetate as the initial substrate (which was subsequently 
deacetylated by the lipase and oxidized by the glucose oxidase), yielding peroxide that was subsequently used by the peroxidize to oxidize ABTS [2,20-azinobis (3-ethylbenzothiazoline-6sulfonic acid)]. Similar uses of compartmentalization and multiple enzymes (laccase and lipase) have been achieved using Spherezymes [251]. $\alpha$-Amylase, cellulase, protease, and lipase have been immobilized individually on various supports. However, Pundir et al. (2012) reported the covalent coimmobilization of commercial $\alpha$-amylase, cellulase, protease, and lipase onto the inner side of a plastic beaker and bristles of a plastic brush, their properties, and use in removal of stain from cloth [252]. Similarly, commercial lipase, glycerol kinase (GK), glycerol-3-phosphate oxidase (GPO) and peroxidase were co-immobilized covalently on to arylamine glass beads [253]. Starch-converting enzymes, $\alpha$-amylase and glucoamylase, were immobilized on surface-modified carriers using a co-immobilized, as well as a single system. The co-enzymes immobilized on hydrophilic silica gel and DEAE-cellulose entrapped in alginate beads exhibited 92.3 and $88.9 \%$ of the remaining activity even after 10 times of reuse [254]. Co-immobilized enzymes have been used extensively in expensive commercial and biological approaches in recent years to develop more economic and environmentally friendly processes.

\subsection{Advances in Enzyme Immobilization}

Recent advancements in nano and hybrid technology have made various materials more affordable hosts for enzyme immobilization. As a result, various nanostructured materials based on combined organic and inorganic species have received attention as enzyme immobilizing supports due to their intrinsic large surface areas and physicochemical properties such as pore size, hydrophilic/hydrophobic balance, aquaphilicity and surface chemistry [255]. Large surface area and controlled pore size often result in improved enzyme loading, which increases enzyme activity per unit mass or volume, compared to that of conventional materials [256]. Nanostructured materials with ability to control size and shape enables better interaction with the enzyme, increases immobilization efficiency, and enhances the long-term storage and recycling stability of the enzyme [257]. In addition, these organic, inorganic or hybrid materials may provide specific features such as enhanced strength, elasticity, plasticity, and chemical bonding in an appropriate microenvironment. Various organic or inorganic nanomaterials such as multiwall carbon nanotubes (MWCNTs), magnetic nanoparticles, silica nanoparticles, and quantum dots have been exploited to generate hybrid composite nanofibers with additional physical properties and mechanical stability [258,259].

Magnetite mesoporous silica hybrid support was fabricated by depositing magnetite and MCM-41 nanoparticles onto polystyrene beads using the layer-by-layer (LBL) method. The incorporation of magnetite gives an additional magnetic property to the hollow mesoporous silica shells to improve the enzyme immobilization. Magnetic/silica nanoparticles with a core of magnetic clusters were applied to stabilization of His-tagged Bacillus stearothermopilus L1 lipase [260]. Xia's group reported on encapsulation of enzymes in nanofibers by direct coelectrospinning [261].

\subsubsection{New Technology for Enzyme Immobilization}

In the last decade, more attention has been paid to the regulation of the microenvironment for the enzyme on a support surface in order to obtain significant stabilization of the immobilized enzyme and 
development of new support. Unfortunately, there have been few studies in enzyme immobilization that have focused on mimicking the environment of a cell to improve the properties of the enzyme in vitro. Moreover, many attempts have been focused on the multipoint covalent attachment of proteins on supports, which has been reported to clearly increase the thermal stability of immobilized enzymes. However, the stabilizing effect increases with the number of covalent bonds between enzymes and the support until some critical value (a limit) is achieved, and a further increase in the number of bonds does not result in further stabilization [262]. Excess activated groups present on the support surface would increase the possibility of enzyme deactivation due to their subsequent slow reaction with the enzyme [168].

\subsubsection{Microwave Irradiation}

Recently, controlled microwave irradiation has been shown to dramatically accelerate chemical reactions and reduce reaction times required for immobilization [263]. It is thought that microwave irradiation provides an additional driving force for mass transport and accelerates the mass transfer [264]. Microwave irradiation has been used to simplify and improve the reaction conditions for many classic organic reactions. Reactions performed under microwave irradiation proceed faster, are cleaner, present much better yields and are more reproducible than those performed under conventional conditions. Microwave assisted heterogeneous oxidation and reduction reactions have received attention in recent years. Varma et al. have demonstrated that the reaction rate of oxidation and reduction reaction under microwave irradiation could be greatly enhanced under microwave irradiation than that under conventional heating [265,266].

Wang et al. have immobilized papain and penicillin acylase in mesocellular siliceous foams (MCFs) by using the microwave irradiation technology [267,268]. 80 and 140 seconds were enough for immobilization of papain and penicillin acylase, respectively. The maximum loading of papain reached $984.1 \mathrm{mg} / \mathrm{g}, 1.26$ times of that obtained from the conventional method which was non-microwave-assisted. The activities of microwave-assisted immobilized papain and penicillin acylase were 1.86 and 1.39 times of those with conventional method. Immobilization of lipases and horseradish peroxidase under microwave-assisted method were reported [269].

\subsubsection{Photoimmobilization Technology}

The protein molecules (e.g., horseradish peroxidase or glucose oxidase), when exposed to ultraviolet (UV) light at $365 \mathrm{~nm}$ along with a photoreactive polymer, were immobilized through covalent bonding by the highly reactive nitrene of the polymer in about 10 to $20 \mathrm{~min}$ [270]. The photoreactive polymer under UV light generates highly reactive nitrene, which has a property of inserting into $\mathrm{C}-\mathrm{H}$ bond and is capable of binding with the biomolecule thus serving important for the immobilization of biomolecules irrespective of their functional groups. However, Kumar and Nahar (2007) reported that horseradish peroxidase and glucose oxidase showed efficient immobilization when placed on the photoreactive cellulose membranes and exposed to sunlight [271]. No detectable increase in immobilization was observed beyond 21,625 lux, which was considered as the sunlight intensity required for optimum immobilization. Thus, sunlight could be a very good alternative compared to $365 \mathrm{~nm}$ UV light for photoimmobilization. Therefore, photoimmobilization is a green technique and suitable for large-scale, as well as small-scale, immobilization. 


\subsubsection{Enzymatic Immobilization of Enzyme}

The use of green chemistry rather than harsh chemicals is one of the main goals in enzyme industries to avoid the partial denaturation of enzyme protein. Enzyme-assisted immobilization of the enzyme is an emerging and novel technology to fabricate solid protein formulations [272,273]. Tanaka et al. (2007) reported the immobilization of enhanced green fluorescent protein (EGFP) and glutathione $S$-transferase (GST) onto the casein-coated polystyrene surface as model proteins. EGFP and GST were tagged with a neutral Gln-donor substrate peptide for MTG (Leu-Leu-Gln-Gly, LLQG-tag) at their $C$-terminus. This strategy has been also applied to immobilize Luciferase (Luc) and GST ybbR-fusion proteins and thioredoxin fusion proteins [273].

\subsubsection{Controlled Immobilization of Enzyme onto Porous Materials.}

Protein distribution (heterogeneous or homogeneous) across a porous material depends on whether the immobilization rate is controlled by either protein/support attachment or mass transference. Bolivar et al. (2011) described different strategies to control the distribution of fluorescent proteins by altering their immobilization rates under low protein loads conditions focusing on the chemical nature of protein-support attachment [274]. The control of protein immobilization by modulation of apparent immobilization rate was extended to the immobilization of two fluorescent proteins onto the same carrier, creating four different distribution patterns. These tailor-made distributions of two proteins inside one single porous carrier are pioneering in immobilization technology. One of these groups is highly reactive under alkaline conditions, thereby promoting intense covalent protein-support attachments, whereas the other group reversibly immobilizes the protein under mild $\mathrm{pH}$ conditions ( $\mathrm{pH}$ 6-8). Another interesting approach to control the distribution of protein is the immobilization of multi-enzyme systems on the same solid surface that is activated by different reactive groups. Recently, Rocha-Martín et al. (2012) reported the co-immobilization of three bio-redox orthogonal cascades that involved a main and a recycling dehydrogenase onto a heterogeneously activated agarose-type support [275]. The agarose-type support was heterogeneously activated with glyoxyl groups and metal chelates to enable the immobilization of proteins through two different techniques.

\subsubsection{Recommendation for the Future of Immobilization Technology}

At present, a vast number of methods for immobilization of enzymes are available. Unfortunately, there is no universal immobilization method, nor a single preferred method of enzyme immobilization. Immobilization method or the choice of support differs from enzyme to enzyme, from application to application and from carrier to carrier. Cao (2005), in his book Carrier Bound Immobilized Enzymes, suggested that the major problem in enzyme immobilization is not only the selection of the right carrier for the enzyme immobilization, but it is how to design the performance of the immobilized enzyme [168]. In the future, information derived from protein sequences, 3D-structures, reaction mechanism, and working environment should be further combined with the properties of supports and immobilization methods in order to produce the immobilized enzyme with enhanced properties for a biochemical application. As methods for the immobilization of enzymes continue to improve and become commercially widespread, the cascade enzymatic reaction and in vitro synthetic biology, 
multi-enzyme immobilization will be one of next goals [276-278]. In addition, with the growing attention paid to the use of in silico technology in various fields of sciences, including protein engineering, the in silico model can be designed to validate the probability of success and the efficiency of the immobilization process before starting the immobilization.

\subsection{Integration of Different Techniques}

There are many reports showing that the enzyme properties may be directly improved by: chemical or genetic modification of enzymes, screening of the most suitable enzyme, and immobilization of enzymes. An excellent example of the coupling of engineering and immobilization is demonstrated by the variants of formate dehydrogenase whereby Candida boidinii preserved 4.4-fold higher activity after entrapment in polyacrylamide gels than the wild-type enzyme [159]. Godoy et al. (2011) reported the site-directed immobilization/rigidification of genetically modified enzymes through multipoint covalent attachment on bifunctional disulfide-glyoxyl supports [279]. Genetically engineered lipase 2 from Geobacillus thermocatenulatus and penicillin $\mathrm{G}$ acylase from E. coli were immobilized and uniquely rigidified by a multipoint covalent attachment onto tailor-made bifunctional disulfide-glyoxyl supports. Therefore, the use of coupled strategy (protein engineering and immobilization) seems to improve the properties of the final immobilized biocatalyst, and, moreover, modulates multiple properties of enzymes for industrial application.

\section{Conclusions}

In this review, we have shown some examples of where the modulation of biochemical and physical properties of engineered and/or immobilized enzymes has been permitted to solve problems such as stability, selectivity, and substrate or solvent tolerance of enzymes. It is clear from this report that protein engineering or immobilization individually cannot make an ideal catalyst for industrial processes. Until now, there has been no universal method to modulate a particular property of an enzyme. Therefore, the combination of protein engineering and immobilization of enzymes seems to be a powerful tool to greatly improve a number of industrial processes, and more effort may be expected in the coming years in this regard. When properly designed, the immobilization of enzymes in combination with protein engineering techniques can be a very successful strategy to improve enzymes of industrial significance.

\section{Acknowledgments}

This research was supported by the Converging Research Center Program through the National Research Foundation of Korea, funded by the Ministry of Education, Science and Technology (Grant 2011-50210). This study was also supported by Brain Pool 2012 of Konkuk University, Republic of Korea.

\section{References}

1. Adamczak, M.; Sajja, K.H. Strategies for improving enzymes for efficient biocatalysis. Food Technol. Biotechnol. 2004, 42, 251-264. 
2. Reetz, M.T.; Carballeira, J.D.; Vogel, A. Iterative saturation mutagenesis on the basis of B factors as a strategy for increasing protein thermostability. Angew. Chem. Int. Ed. 2006, 45, 7745-7751.

3. Bommarius, A.S.; Riebel-Bommarius, B.R. Biocatalysis: Fundamentals and Applications; Wiley-VCH: Weinheim, Germany, 2004; p. 611.

4. Katchalski-Katzir, E.; Kraemer, D.M. Eupergit C, a carrier for immobilization of enzymes of industrial potential. J. Mol. Catal. B 2000, 10, 157-176.

5. Straathof, A.J.J.; Panke, S.; Schmid, A. The production of fine chemicals by biotransformations. Curr. Opin. Biotechnol. 2002, 13, 548-556.

6. Polizzi, K.M.; Bommarius, A.S.; Broering, J.M.; Chaparro-Riggers, J.F. Stability of biocatalysts. Curr. Opin. Chem. Biol. 2007, 11, 220-225.

7. May, O.; Nguyen, P.T.; Arnold, F.H. Inverting enantioselectivity by directed evolution of hydantoinase for improved production of L-methionine. Nat. Biotechnol. 2000, 18, 317-320.

8. Lee, S.H.; Kim, Y.W.; Lee, S.; Auh, J.H.; Yoo, S.S.; Kim, T.J.; Kim, J.W.; Kim, S.T.; Rho, H.J.; Choi, J.H.; et al. Modulation of cyclizing activity and thermostability of cyclodextrin glucanotransferase and its application as an antistaling enzyme. J. Agric. Food Chem. 2002, 50, 1411-1415.

9. Zhang, N.; Suen, W.C.; Windsor, W.; Xiao, L.; Madison, V.; Zaks, A. Improving tolerance of Candida antarctica lipase B towards irreversible thermal inactivation through directed evolution. Protein Eng. 2003, 16, 599-605.

10. Williams, G.J.; Domann, S.; Nelson, A.; Berry, A. Modifying the stereochemistry of an enzyme-catalyzed reaction by directed evolution. Proc. Natl. Acad. Sci. USA 2003, 100, 3143-3148.

11. Sriprapundh, D.; Vieille, C.; Zeikus, J.G. Directed evolution of Thermotoga neapolitana xylose isomerase: High activity on glucose at low temperature and low pH. Protein Eng. 2003, 16, 683-690.

12. Van der Veen, B.A.; Potocki-Veronese, G.; Albenne, C.; Joucla, G.; Monsan, P.; Remaud-Simeon, M. Combinatorial engineering to enhance amylosucrase performance: Construction, selection, and screening of variant libraries for increased activity. FEBS Lett. 2004, 560, 91-97.

13. Wilkinson, D.; Akumanyi, N.; Hurtado-Guerrero, R.; Dawkes, H.; Knowles, P.F.; Phillips, S.E.; McPherson, M.J. Structural and kinetic studies of a series of mutants of galactose oxidase identified by directed evolution. Protein Eng. Des. Sel. 2004, 17, 141-148.

14. Hao, J.; Berry, A. A thermostable variant of fructose bisphosphate aldolase constructed by directed evolution also shows increased stability in organic solvents. Protein Eng. Des. Sel. 2004, $17,689-697$.

15. Wen, T.N.; Chen, J.L.; Lee, S.H.; Yang, N.S.; Shyur, L.F. A truncated Fibrobacter succinogenes $1,3-1,4-\beta$-D-glucanase with improved enzymatic activity and thermotolerance. Biochemistry 2005, 44, 9197-9205.

16. Fujii, R.; Nakagawa, Y.; Hiratake, J.; Sogabe, A.; Sakata, K. Directed evolution of Pseudomonas aeruginosa lipase for improved amide-hydrolyzing activity. Protein Eng. Des. Sel. 2005, 18, 93-101. 
17. Tobe, S.; Shimogaki, H.; Ohdera, M.; Asai, Y.; Oba, K.; Iwama, M.; Irie, M. Expression of Bacillus protease (Protease BYA) from Bacillus sp. Y in Bacillus subtilis and enhancement of its specific activity by site-directed mutagenesis-improvement in productivity of detergent enzyme. Biol. Pharm. Bull. 2006, 29, 26-33.

18. Suemori, A.; Iwakura, M. A systematic and comprehensive combinatorial approach to simultaneously improve the activity, reaction specificity, and thermal stability of p-hydroxybenzoate hydroxylase. J. Biol. Chem. 2007, 282, 19969-19978.

19. Fenel, F.; Zitting, A.J.; Kantelinen, A. Increased alkali stability in Trichoderma reesei endo-1,4- $\beta$-xylanase II by site directed mutagenesis. J. Biotechnol. 2006, 121, 102-107.

20. Jones, A.; Lamsa, M.; Frandsen, T.P.; Spendler, T.; Harris, P.; Sloma, A.; Xu, F.; Nielsen, J.B.; Cherry, J.R. Directed evolution of a maltogenic $\alpha$-amylase from Bacillus sp. TS-25. J. Biotechnol. 2008, 134, 325-333.

21. Dumon, C.; Varvak, A.; Wall, M.A.; Flint, J.E.; Lewis, R.J.; Lakey, J.H.; Morland, C.; Luginbuhl, P.; Healey, S.; Todaro, T.; et al. Engineering hyperthermostability into a GH11 xylanase is mediated by subtle changes to protein structure. J. Biol. Chem. 2008, 283, 22557-22564.

22. Hirokawa, K.; Ichiyanagi, A.; Kajiyama, N. Enhancement of thermostability of fungal deglycating enzymes by directed evolution. Appl. Microbiol. Biotechnol. 2008, 78, 775-781.

23. Belien, T.; Joye, I.J.; Delcour, J.A.; Courtin, C.M. Computational design-based molecular engineering of the glycosyl hydrolase family 11 B. subtilis XynA endoxylanase improves its acid stability. Protein Eng. Des. Sel. 2009, 22, 587-596.

24. Zhong, C.Q.; Song, S.; Fang, N.; Liang, X.; Zhu, H.; Tang, X.F.; Tang, B. Improvement of low-temperature caseinolytic activity of a thermophilic subtilase by directed evolution and site-directed mutagenesis. Biotechnol. Bioeng. 2009, 104, 862-870.

25. Gupta, N.; Farinas, E.T. Directed evolution of CotA laccase for increased substrate specificity using Bacillus subtilis spores. Protein Eng. Des. Sel. 2010, 23, 679-682.

26. Spadiut, O.; Nguyen, T.T.; Haltrich, D. Thermostable variants of pyranose 2-oxidase showing altered substrate selectivity for glucose and galactose. J. Agric. Food Chem. 2010, 58, 3465-3471.

27. Zhang, Z.G.; Yi, Z.L.; Pei, X.Q.; Wu, Z.L. Improving the thermostability of Geobacillus stearothermophilus xylanase XT6 by directed evolution and site-directed mutagenesis. Bioresour. Technol. 2010, 101, 9272-9278.

28. Bustos-Jaimes, I.; Mora-Lugo, R.; Calcagno, M.L.; Farres, A. Kinetic studies of Gly28:Ser mutant form of Bacillus pumilus lipase: Changes in $\mathrm{k}_{\mathrm{cat}}$ and thermal dependence. Biochim. Biophys. Acta 2010, 1804, 2222-2227.

29. Sun, J.; Wang, H.; Lv, W.; Ma, C.; Lou, Z.; Dai, Y. Construction and characterization of a fusion $\beta-1,3-1,4$-glucanase to improve hydrolytic activity and thermostability. Biotechnol. Lett. 2011, 33, 2193-2199.

30. Lee, S.; Lee, D.G.; Jang, M.K.; Jeon, M.J.; Jang, H.J.; Lee, S.H. Improvement in the catalytic activity of $\beta$-agarase AgaA from Zobellia galactanivorans by site-directed mutagenesis. J. Microbiol. Biotechnol. 2011, 21, 1116-1122.

31. Theriot, C.M.; Semcer, R.L.; Shah, S.S.; Grunden, A.M. Improving the catalytic activity of hyperthermophilic Pyrococcus horikoshii prolidase for detoxification of organophosphorus nerve agents over a broad range of temperatures. Archaea 2011, 2011, doi:10.1155/2011/565127. 
32. Shih, T.W.; Pan, T.M. Substitution of Asp189 residue alters the activity and thermostability of Geobacillus sp. NTU 03 lipase. Biotechnol. Lett. 2011, 33, 1841-1846.

33. Hokanson, C.A.; Cappuccilli, G.; Odineca, T.; Bozic, M.; Behnke, C.A.; Mendez, M.; Coleman, W.J.; Crea, R. Engineering highly thermostable xylanase variants using an enhanced combinatorial library method. Protein Eng. Des. Sel. 2011, 24, 597-605.

34. Ben Mabrouk, S.; Aghajari, N.; Ben Ali, M.; Ben Messaoud, E.; Juy, M.; Haser, R.; Bejar, S. Enhancement of the thermostability of the maltogenic amylase MAUS149 by Gly312Ala and Lys436Arg substitutions. Bioresour. Technol. 2011, 102, 1740-1746.

35. Sun, Y.; Yang, H.; Wang, W. Improvement of the thermostability and enzymatic activity of cholesterol oxidase by site-directed mutagenesis. Biotechnol. Lett. 2011, 33, 2049-2055.

36. Le, Q.A.; Joo, J.C.; Yoo, Y.J.; Kim, Y.H. Development of thermostable Candida antarctica lipase B through novel in silico design of disulfide bridge. Biotechnol. Bioeng. 2012, 109, 867-876.

37. Mollania, N.; Khajeh, K.; Ranjbar, B.; Hosseinkhani, S. Enhancement of a bacterial laccase thermostability through directed mutagenesis of a surface loop. Enzyme Microb. Technol. 2011, $49,446-452$.

38. Choi, J.G.; Ju, Y.H.; Yeom, S.J.; Oh, D.K. Improvement in the thermostability of D-psicose 3-epimerase from Agrobacterium tumefaciens by random and site-directed mutagenesis. Appl. Environ. Microbiol. 2011, 77, 7316-7320.

39. Huang, J.W.; Cheng, Y.S.; Ko, T.P.; Lin, C.Y.; Lai, H.L.; Chen, C.C.; Ma, Y.; Zheng, Y.; Huang, C.H.; Zou, P.; et al. Rational design to improve thermostability and specific activity of the truncated Fibrobacter succinogenes 1,3-1,4- $\beta$-D-glucanase. Appl. Microbiol. Biotechnol. 2012, 94, 111-121.

40. Liu, Y.H.; Hu, B.; Xu, Y.J.; Bo, J.X.; Fan, S.; Wang, J.L.; Lu, F.P. Improvement of the acid stability of Bacillus licheniformis a amylase by error-prone PCR. J. Appl. Microbiol. 2012, 113, 541-549.

41. Yang, H.; Liu, L.; Wang, M.; Li, J.; Wang, N.S.; Du, G.; Chen, J. Structure-based engineering of methionine residues in the catalytic cores of alkaline amylase from Alkalimonas amylolytica for improved oxidative stability. Appl. Environ. Microbiol. 2012, 78, 7519-7526.

42. Srikrishnan, S.; Randall, A.; Baldi, P.; Da Silva, N.A. Rationally selected single-site mutants of the Thermoascus aurantiacus endoglucanase increase hydrolytic activity on cellulosic substrates. Biotechnol. Bioeng. 2012, 109, 1595-1599.

43. Nishioka, T.; Yasutake, Y.; Nishiya, Y.; Tamura, T. Structure-guided mutagenesis for the improvement of substrate specificity of Bacillus megaterium glucose 1-dehydrogenase IV. FEBS J. 2012, 279, 3264-3275.

44. Qi, X.; Guo, Q.; Wei, Y.; Xu, H.; Huang, R. Enhancement of pH stability and activity of glycerol dehydratase from Klebsiella pneumoniae by rational design. Biotechnol. Lett. 2012, 34, 339-346.

45. Goh, P.H.; Illias, R.M.; Goh, K.M. Rational mutagenesis of cyclodextrin glucanotransferase at the calcium binding regions for enhancement of thermostability. Int. J. Mol. Sci. 2012, 13, 5307-5323.

46. Ye, X.; Zhang, C.; Zhang, Y.H. Engineering a large protein by combined rational and random approaches: Stabilizing the Clostridium thermocellum cellobiose phosphorylase. Mol. Biosyst. 2012, 8, 1815-1823. 
47. Kumar, A.; Dutt, S.; Bagler, G.; Ahuja, P.S.; Kumar, S. Engineering a thermo-stable superoxide dismutase functional at sub-zero to $>50{ }^{\circ} \mathrm{C}$, which also tolerates autoclaving. Sci. Rep. 2012, 2 , 387:1-387:8.

48. Anbar, M.; Gul, O.; Lamed, R.; Sezerman, U.O.; Bayer, E.A. Improved thermostability of Clostridium thermocellum endoglucanase Ce18A by using consensus-guided mutagenesis. Appl. Environ. Microbiol. 2012, 78, 3458-3464.

49. Wang, Y.; Yuan, H.; Wang, J.; Yu, Z. Truncation of the cellulose binding domain improved thermal stability of endo- $\beta-1,4$-glucanase from Bacillus subtilis JA18. Bioresour. Technol. 2009, 100, 345-349.

50. Spadiut, O.; Radakovits, K.; Pisanelli, I.; Salaheddin, C.; Yamabhai, M.; Tan, T.C.; Divne, C.; Haltrich, D. A thermostable triple mutant of pyranose 2-oxidase from Trametes multicolor with improved properties for biotechnological applications. Biotechnol. J. 2009, 4, 525-534.

51. Rha, E.; Kim, S.; Choi, S.L.; Hong, S.P.; Sung, M.H.; Song, J.J.; Lee, S.G. Simultaneous improvement of catalytic activity and thermal stability of tyrosine phenol-lyase by directed evolution. FEBS J. 2009, 276, 6187-6194.

52. Zhao, Q.; Liu, H.; Zhang, Y. Engineering of protease-resistant phytase from Penicillium sp.: High thermal stability, low optimal temperature and pH. J. Biosci. Bioeng. 2010, 110, 638-645.

53. Kotzia, G.A.; Labrou, N.E. Engineering thermal stability of L-asparaginase by in vitro directed evolution. FEBS J. 2009, 276, 1750-1761.

54. Yi, Z.L.; Pei, X.Q.; Wu, Z.L. Introduction of glycine and proline residues onto protein surface increases the thermostability of endoglucanase CelA from Clostridium thermocellum. Bioresour. Technol. 2011, 102, 3636-3638.

55. Pei, X.Q.; Yi, Z.L.; Tang, C.G.; Wu, Z.L. Three amino acid changes contribute markedly to the thermostability $\beta$-glucosidase BglC from Thermobifida fusca. Bioresour. Technol. 2011, 102, 3337-3342.

56. Damnjanovic, J.; Takahashi, R.; Suzuki, A.; Nakano, H.; Iwasaki, Y. Improving thermostability of phosphatidylinositol-synthesizing Streptomyces phospholipase D. Protein Eng. Des. Sel. 2012, 25, 415-424.

57. Lee, H.L.; Chang, C.K.; Jeng, W.Y.; Wang, A.H.; Liang, P.H. Mutations in the substrate entrance region of $\beta$-glucosidase from Trichoderma reesei improve enzyme activity and thermostability. Protein Eng. Des. Sel. 2012, 25, 733-740.

58. Sharma, P.K.; Kumar, R.; Mohammad, O.; Singh, R.; Kaur, J. Engineering of a metagenome derived lipase toward thermal tolerance: Effect of asparagine to lysine mutation on the protein surface. Gene 2012, 491, 264-271.

59. Camarero, S.; Pardo, I.; Canas, A.I.; Molina, P.; Record, E.; Martinez, A.T.; Martinez, M.J.; Alcalde, M. Engineering platforms for directed evolution of Laccase from Pycnoporus cinnabarinus. Appl. Environ. Microbiol. 2012, 78, 1370-1384.

60. Zhang, S.B.; Pei, X.Q.; Wu, Z.L. Multiple amino acid substitutions significantly improve the thermostability of feruloyl esterase A from Aspergillus niger. Bioresour. Technol. 2012, 117, 140-147. 
61. Brode, P.F., III; Erwin, C.R.; Rauch, D.S.; Barnett, B.L.; Armpriester, J.M.; Wang, E.S.; Rubingh, D.N. Subtilisin BPN' variants: Increased hydrolytic activity on surface-bound substrates via decreased surface activity. Biochemistry 1996, 35, 3162-3169.

62. Rubingh, D.N. The influence of surfactants on enzyme activity. Curr. Opin. Coll. Int. Sci. 1996, 1, 598-603.

63. Beer, H.D.; Wohlfahrt, G.; McCarthy, J.E.; Schomburg, D.; Schmid, R.D. Analysis of the catalytic mechanism of a fungal lipase using computer-aided design and structural mutants. Protein Eng. 1996, 9, 507-517.

64. Martinelle, M.; Holmquist, M.; Clausen, I.G.; Patkar, S.; Svendsen, A.; Hult, K. The role of Glu87 and Trp89 in the lid of Humicola lanuginosa lipase. Protein Eng. 1996, 9, 519-524.

65. Pedersen, S.; Lange, N.K.; Nissen, A.M. Novel industrial enzyme applications. Ann. N. Y. Acad. Sci. 1995, 750, 376-390.

66. Jeffries, T.W. Enzyme Technology for Pulp Bleaching and Deinking. International Business Communications: Southbourough, MA, USA, 1996; pp. 81-97.

67. Koivula, A.; Reinikainen, T.; Ruohonen, L.; Valkeajarvi, A.; Claeyssens, M.; Teleman, O.; Kleywegt, G.J.; Szardenings, M.; Rouvinen, J.; Jones, T.A.; et al. The active site of Trichoderma reesei cellobiohydrolase II: The role of tyrosine 169. Protein Eng. 1996, 9, 691-699.

68. Jeffries, T.W. Biochemistry and genetics of microbial xylanases. Curr. Opin. Biotechnol. 1996, 7, 337-342.

69. Cherry, J.R.; Lamsa, M.H.; Schneider, P.; Vind, J.; Svendsen, A.; Jones, A.; Pedersen, A.H. Directed evolution of a fungal peroxidase. Nat. Biotechnol. 1999, 17, 379-384.

70. Martin, A.; Sieber, V.; Schmid, F.X. In-vitro selection of highly stabilized protein variants with optimized surface. J. Mol. Biol. 2001, 309, 717-726.

71. Palackal, N.; Brennan, Y.; Callen, W.N.; Dupree, P.; Frey, G.; Goubet, F.; Hazlewood, G.P.; Healey, S.; Kang, Y.E.; Kretz, K.A.; et al. An evolutionary route to xylanase process fitness. Protein Sci. 2004, 13, 494-503.

72. Schmidt-Dannert, C.; Arnold, F.H. Directed evolution of industrial enzymes. Trends Biotechnol. 1999, 17, 135-136.

73. Zhao, H.; Arnold, F.H. Directed evolution converts subtilisin E into a functional equivalent of thermitase. Protein Eng. 1999, 12, 47-53.

74. Miyazaki, K.; Wintrode, P.L.; Grayling, R.A.; Rubingh, D.N.; Arnold, F.H. Directed evolution study of temperature adaptation in a psychrophilic enzyme. J. Mol. Biol. 2000, 297, 1015-1026.

75. Gershenson, A.; Schauerte, J.A.; Giver, L.; Arnold, F.H. Tryptophan phosphorescence study of enzyme flexibility and unfolding in laboratory-evolved thermostable esterases. Biochemistry 2000, 39, 4658-4665.

76. Giver, L.; Gershenson, A.; Freskgard, P.O.; Arnold, F.H. Directed evolution of a thermostable esterase. Proc. Natl. Acad. Sci. USA 1998, 95, 12809-12813.

77. Suzuki, T.; Yasugi, M.; Arisaka, F.; Yamagishi, A.; Oshima, T. Adaptation of a thermophilic enzyme, 3-isopropylmalate dehydrogenase, to low temperatures. Protein Eng. 2001, 14, 85-91.

78. Tamakoshi, M.; Nakano, Y.; Kakizawa, S.; Yamagishi, A.; Oshima, T. Selection of stabilized 3-isopropylmalate dehydrogenase of Saccharomyces cerevisiae using the host-vector system of an extreme thermophile, Thermus thermophilus. Extremophiles 2001, 5, 17-22. 
79. Hardy, F.; Vriend, G.; Veltman, O.R.; van der Vinne, B.; Venema, G.; Eijsink, V.G. Stabilization of Bacillus stearothermophilus neutral protease by introduction of prolines. FEBS Lett. 1993, 317, 89-92.

80. Mansfeld, J.; Vriend, G.; Dijkstra, B.W.; Veltman, O.R.; van den Burg, B.; Venema, G.; Ulbrich-Hofmann, R.; Eijsink, V.G. Extreme stabilization of a thermolysin-like protease by an engineered disulfide bond. J. Biol. Chem. 1997, 272, 11152-11156.

81. Veltman, O.R.; Vriend, G.; Middelhoven, P.J.; van den Burg, B.; Venema, G.; Eijsink, V.G. Analysis of structural determinants of the stability of thermolysin-like proteases by molecular modelling and site-directed mutagenesis. Protein Eng. 1996, 9, 1181-1189.

82. Van den Burg, B.; Vriend, G.; Veltman, O.R.; Venema, G.; Eijsink, V.G. Engineering an enzyme to resist boiling. Proc. Natl. Acad. Sci. USA 1998, 95, 2056-2060.

83. Kawamura, S.; Kakuta, Y.; Tanaka, I.; Hikichi, K.; Kuhara, S.; Yamasaki, N.; Kimura, M. Glycine-15 in the bend between two $\alpha$-helices can explain the thermostability of DNA binding protein HU from Bacillus stearothermophilus. Biochemistry 1996, 35, 1195-1200.

84. Kimura, S.; Kanaya, S.; Nakamura, H. Thermostabilization of Escherichia coli ribonuclease HI by replacing left-handed helical Lys95 with Gly or Asn. J. Biol. Chem. 1992, 267, 22014-22017.

85. Matthews, B.W.; Nicholson, H.; Becktel, W.J. Enhanced protein thermostability from site-directed mutations that decrease the entropy of unfolding. Proc. Natl. Acad. Sci. USA 1987, $84,6663-6667$.

86. Sanz-Aparicio, J.; Hermoso, J.A.; Martínez-Ripoll, M.; González, B.; López-Camacho, C.; Polaina, J. Structural basis of increased resistance to thermal denaturation induced by single amino acid substitution in the sequence of $\beta$-glucosidase A from Bacillus polymyxa. Proteins Struct. Funct. Bioinforma. 1998, 33, 567-576.

87. Tiwari, M.K.; Moon, H.J.; Jeya, M.; Lee, J.K. Cloning and characterization of a thermostable xylitol dehydrogenase from Rhizobium etli CFN42. Appl. Microbiol. Biotechnol. 2010, 87, 571-581.

88. Wintrode, P.L.; Arnold, F.H. Temperature adaptation of enzymes: Lessons from laboratory evolution. Adv. Protein Chem. 2000, 55, 161-225.

89. Zhang, X.J.; Baase, W.A.; Shoichet, B.K.; Wilson, K.P.; Matthews, B.W. Enhancement of protein stability by the combination of point mutations in T4 lysozyme is additive. Protein Eng. 1995, 8, 1017-1022.

90. Lehmann, M.; Loch, C.; Middendorf, A.; Studer, D.; Lassen, S.F.; Pasamontes, L.; van Loon, A.P.; Wyss, M. The consensus concept for thermostability engineering of proteins: Further proof of concept. Protein Eng. 2002, 15, 403-411.

91. D’Amico, S.; Marx, J.C.; Gerday, C.; Feller, G. Activity-stability relationships in extremophilic enzymes. J. Biol. Chem. 2003, 278, 7891-7896.

92. Sandgren, M.; Gualfetti, P.J.; Shaw, A.; Gross, L.S.; Saldajeno, M.; Day, A.G.; Jones, T.A.; Mitchinson, C. Comparison of family 12 glycoside hydrolases and recruited substitutions important for thermal stability. Protein Sci. 2003, 12, 848-860.

93. Williams, J.C.; Zeelen, J.P.; Neubauer, G.; Vriend, G.; Backmann, J.; Michels, P.A.; Lambeir, A.M.; Wierenga, R.K. Structural and mutagenesis studies of leishmania triosephosphate isomerase: A point mutation can convert a mesophilic enzyme into a superstable enzyme without losing catalytic power. Protein Eng. 1999, 12, 243-250. 
94. Hasegawa, J.; Shimahara, H.; Mizutani, M.; Uchiyama, S.; Arai, H.; Ishii, M.; Kobayashi, Y.; Ferguson, S.J.; Sambongi, Y.; Igarashi, Y. Stabilization of Pseudomonas aeruginosa cytochrome $\mathrm{c}_{551}$ by systematic amino acid substitutions based on the structure of thermophilic Hydrogenobacter thermophilus cytochrome $\mathrm{c}_{552}$. J. Biol. Chem. 1999, 274, 37533-37537.

95. Khmelnitsky, Y.L.; Rich, J.O. Biocatalysis in nonaqueous solvents. Curr. Opin. Chem. Biol. 1999, 3, 47-53.

96. Arnold, F.H. Engineering enzymes for non-aqueous solvents. Trends. Biotechnol. 1990, 8, 244-249.

97. Dordick, J.S. Enzymatic catalysis in monophasic organic solvents. Enzyme Microb. Technol. 1989, 11, 194-211.

98. Wong, C.H.; Chen, S.T.; Hennen, W.J.; Bibbs, J.A.; Wang, Y.F.; Liu, J.L.C.; Pantoliano, M.W.; Whitlow, M.; Bryan, P.N. Enzymes in organic synthesis: Use of subtilisin and a highly stable mutant derived from multiple site-specific mutations. J. Am. Chem. Soc. 1990, 112, 945-953.

99. Chen, K.Q.; Arnold, F.H. Enzyme engineering for nonaqueous solvents: Random mutagenesis to enhance activity of subtilisin E in polar organic media. Biotechnology 1991, 9, 1073-1077.

100. Economou, C.; Chen, K.; Arnold, F.H. Random mutagenesis to enhance the activity of subtilisin in organic solvents: Characterization of Q103R subtilisin E. Biotechnol. Bioeng. 1992, 39, 658-662.

101. Pantoliano, M.W. Proteins designed for challenging environments and catalysis in organic solvents. Curr. Opin. Struct. Biol. 1992, 2, 559-568.

102. Moore, J.C.; Arnold, F.H. Directed evolution of a $p$-nitrobenzyl esterase for aqueous-organic solvents. Nat. Biotechnol. 1996, 14, 458-467.

103. Martinez, P.; van Dam, M.E.; Robinson, A.C.; Chen, K.; Arnold, F.H. Stabilization of substilisin $\mathrm{E}$ in organic solvents by site-directed mutagenesis. Biotechnol. Bioeng. 1992, 39, 141-147.

104. Song, J.K.; Rhee, J.S. Enhancement of stability and activity of phospholipase $A_{1}$ in organic solvents by directed evolution. Biochim. Biophys. Acta 2001, 1547, 370-378.

105. Morawski, B.; Quan, S.; Arnold, F.H. Functional expression and stabilization of horseradish peroxidase by directed evolution in Saccharomyces cerevisiae. Biotechnol. Bioeng. 2001, 76, 99-107.

106. Liebeton, K.; Zonta, A.; Schimossek, K.; Nardini, M.; Lang, D.; Dijkstra, B.W.; Reetz, M.T.; Jaeger, K.E. Directed evolution of an enantioselective lipase. Chem. Biol. 2000, 7, 709-718.

107. Jaeger, K.E.; Eggert, T.; Eipper, A.; Reetz, M.T. Directed evolution and the creation of enantioselective biocatalysts. Appl. Microbiol. Biotechnol. 2001, 55, 519-530.

108. Nardini, M.; Lang, D.A.; Liebeton, K.; Jaeger, K.E.; Dijkstra, B.W. Crystal structure of Pseudomonas aeruginosa lipase in the open conformation. The prototype for family I.1 of bacterial lipases. J. Biol. Chem. 2000, 275, 31219-31225.

109. Raillard, S.; Krebber, A.; Chen, Y.; Ness, J.E.; Bermudez, E.; Trinidad, R.; Fullem, R.; Davis, C.; Welch, M.; Seffernick, J.; et al. Novel enzyme activities and functional plasticity revealed by recombining highly homologous enzymes. Chem. Biol. 2001, 8, 891-898.

110. Fong, S.; Machajewski, T.D.; Mak, C.C.; Wong, C. Directed evolution of D-2-keto-3-deoxy-6phosphogluconate aldolase to new variants for the efficient synthesis of D- and L-sugars. Chem. Biol. 2000, 7, 873-883. 
111. Wymer, N.; Buchanan, L.V.; Henderson, D.; Mehta, N.; Botting, C.H.; Pocivavsek, L.; Fierke, C.A.; Toone, E.J.; Naismith, J.H. Directed evolution of a new catalytic site in 2-keto-3deoxy-6-phosphogluconate aldolase from Escherichia coli. Structure 2001, 9, 1-9.

112. Suenaga, H.; Goto, M.; Furukawa, K. Emergence of multifunctional oxygenase activities by random priming recombination. J. Biol. Chem. 2001, 276, 22500-22506.

113. Lee, J.K.; Simurdiak, M.; Zhao, H. Reconstitution and characterization of aminopyrrolnitrin oxygenase, a rieske $N$-oxygenase that catalyzes unusual arylamine oxidation. J. Biol. Chem. 2005, 280, 36719-36727.

114. Lee, J.K.; Zhao, H. Mechanistic studies on the conversion of arylamines into arylnitro compounds by aminopyrrolnitrin oxygenase: Identification of intermediates and kinetic studies. Angew. Chem. Int. Ed. 2006, 45, 622-625.

115. Lee, J.K.; Ang, E.L.; Zhao, H. Probing the substrate specificity of aminopyrrolnitrin Oxygenase (PrnD) by mutational analysis. J. Bacteriol. 2006, 188, 6179-6183.

116. Jackson, C.J.; Foo, J.L.; Tokuriki, N.; Afriat, L.; Carr, P.D.; Kim, H.K.; Schenk, G.; Tawfik, D.S.; Ollis, D.L. Conformational sampling, catalysis, and evolution of the bacterial phosphotriesterase. Proc. Natl. Acad. Sci. USA 2009, 106, 21631-21636.

117. Foo, J.L.; Jackson, C.J.; Carr, P.D.; Kim, H.K.; Schenk, G.; Gahan, L.R.; Ollis, D.L. Mutation of outer-shell residues modulates metal ion co-ordination strength in a metalloenzyme. Biochem. J. 2010, 429, 313-321.

118. Saunders, R.; Deane, C.M. Protein structure prediction begins well but ends badly. Proteins 2010, 78, 1282-1290.

119. Zhang, Y. Protein structure prediction: When is it useful? Curr. Opin. Struct. Biol. 2009, 19, 145-155.

120. Zhang, Y. Progress and challenges in protein structure prediction. Curr. Opin. Struct. Biol. 2008, 18, 342-348.

121. Taylor, R.D.; Jewsbury, P.J.; Essex, J.W. A review of protein-small molecule docking methods. J. Comput. Aided Mol. Des. 2002, 16, 151-66.

122. Foo, J.L.; Ching, C.B.; Chang, M.W.; Leong, S.S. The imminent role of protein engineering in synthetic biology. Biotechnol. Adv. 2012, 30, 541-549.

123. Jackson, C.J.; Weir, K.; Herlt, A.; Khurana, J.; Sutherland, T.D.; Horne, I.; Easton, C.; Russell, R.J.; Scott, C.; Oakeshott, J.G. Structure-based rational design of a phosphotriesterase. Appl. Environ. Microbiol. 2009, 75, 5153-5156.

124. Jackson, C.J.; Foo, J.L.; Kim, H.K.; Carr, P.D.; Liu, J.W.; Salem, G.; Ollis, D.L. In crystallo capture of a Michaelis complex and product-binding modes of a bacterial phosphotriesterase. J. Mol. Biol. 2008, 375, 1189-1196.

125. Ugwumba, I.N.; Ozawa, K.; Xu, Z.Q.; Ely, F.; Foo, J.L.; Herlt, A.J.; Coppin, C.; Brown, S.; Taylor, M.C.; Ollis, D.L.; et al. Improving a natural enzyme activity through incorporation of unnatural amino acids. J. Am. Chem. Soc. 2011, 133, 326-333.

126. Voloshchuk, N.; Montclare, J.K. Incorporation of unnatural amino acids for synthetic biology. Mol. Biosyst. 2010, 6, 65-80. 
127. Goldstein, L.; Levin, Y.; Katchalski, E. A water-insoluble polyanionic derivatives of trypsin, effect of the polyelectrolyte carrier on the kinetic behaviour of the bound trypsin. Biochemistry 1964, 3, 1914-1919.

128. Goto, M.; Hatanaka, C.; Goto, M. Immobilization of surfactant-lipase complexes and their high heat resistance in organic media. Biochem. Eng. J. 2005, 24, 91-94.

129. Cabana, H.; Jones, J.P.; Agathos, S.N. Preparation and characterization of cross-linked laccase aggregates and their application to the elimination of endocrine disrupting chemicals. J. Biotechnol. 2007, 132, 23-31.

130. Sangeetha, K.; Abraham, T.E. Preparation and characterization of cross-linked enzyme aggregates (CLEA) of subtilisin for controlled release applications. Int. J. Biol. Macromol. 2008, 43, 314-319.

131. Hirsh, S.L.; Bilek, M.M.; Nosworthy, N.J.; Kondyurin, A.; dos Remedios, C.G.; McKenzie, D.R. A comparison of covalent immobilization and physical adsorption of a cellulase enzyme mixture. Langmuir 2010, 26, 14380-14388.

132. Dickensheets, P.A.; Chen, L.F.; Tsao, G.T. Characteristics of yeast invertase immobilized on porous cellulose beads. Biotechnol. Bioeng. 1977, 19, 365-375.

133. Turkova, J. Oriented immobilization of biologically active proteins as a tool for revealing protein interactions and function. J. Chromatogr. B 1999, 722, 11-31.

134. Taylor, R.F. A comparison of various commercially-available liquid chromatographic supports for immobilization of enzymes and immunoglobulins. Analytica. Chimica. Acta 1985, 172, 241-248.

135. Aloulou, A.; Rodriguez, J.A.; Fernandez, S.; Oosterhout, D.V.; Puccinelli, D.; Carrière, F. Exploring the specific features of interfacial enzymology based on lipase studies. Biochim. Biophys. Acta 2006, 1761, 995-1013.

136. Palomo, J.M. Lipases enantioselectivity alteration by immobilization techniques. Curr. Bioact. Compd. 2008, 4, 126-138.

137. Brady, L.; Brzozowski, A.M.; Derewenda, Z.S.; Dodson, E.; Dodson, G.; Tolley, S.; Turkenburg, J.P.; Christiansen, L.; Huge-Jensen, B.; Norskov, L.; et al. A serine protease triad forms the catalytic centre of a triacylglycerol lipase. Nature 1990, 343, 767-770.

138. Brzozowski, A.M.; Derewenda, U.; Derewenda, Z.S.; Dodson, G.G.; Lawson, D.M.; Turkenburg, J.P.; Bjorkling, F.; Huge-Jensen, B.; Patkar, S.A.; Thim, L. A model for interfacial activation in lipases from the structure of a fungal lipase-inhibitor complex. Nature 1991, 351, 491-494.

139. Derewenda, U.; Brzozowski, A.M.; Lawson, D.M.; Derewenda, Z.S. Catalysis at the interface: The anatomy of a conformational change in a triglyceride lipase. Biochemistry 1992, 31, 1532-1541.

140. Kanori, M.; Hori, T.; Yamashita, Y.; Hirose, Y.; Naoshima, Y. A new inorganic ceramic support, Toyonite and the reactivity and enantioselectivity of the immobilised lipase. J. Mol. Catal. 2000, 9, 269-274.

141. Jia, H.; Zhu, G.; Wang, P. Catalytic behaviors of enzymes attached to nanoparticles: The effect of particle mobility. Biotechnol. Bioeng. 2003, 84, 406-414.

142. Tu, M.; Zhang, X.; Kurabi, A.; Gilkes, N.; Mabee, W.; Saddler, J. Immobilization of $\beta$-glucosidase on Eupergit C for lignocellulose hydrolysis. Biotechnol. Lett. 2006, 28, 151-156. 
143. Pandey, P.; Singh, S.P.; Arya, S.K.; Gupta, V.; Datta, M.; Singh, S.; Malhotra, B.D. Application of thiolated gold nanoparticles for the enhancement of glucose oxidase activity. Langmuir 2007, 23, 3333-3337.

144. Prakasham, R.S.; Devi, G.S.; Laxmi, K.R.; Rao, C.S. Novel synthesis of ferric impregnated silica nanoparticles and their evaluation as a matrix for enzyme immobilization. J. Phys. Chem. C 2007, 111, 3842-3847.

145. Neri, D.F.M.; Balcäo, V.M.; Costa, R.S.; Rocha, I.C.A.P.; Ferreira, E.M.F.C.; Torres, D.P.M.; Rodrigues, L.R.M.; Carvalho, L.B.; Teixeira, J.A. Galacto-oligosaccharides production during lactose hydrolysis by free Aspergillus oryzae $\beta$-galactosidase and immobilized on magnetic polysiloxane-polyvinyl alcohol. Food Chem. 2009, 115, 92-99.

146. Konwarh, R.; Karak, N.; Rai, S.K.; Mukherjee, A.K. Polymer-assisted iron oxide magnetic nanoparticle immobilized keratinase. Nanotechnology 2009, 20, 225107-225117.

147. Qiu, H.; Lu, L.; Huang, X.; Zhang, Z.; Qu, Y. Immobilization of horseradish peroxidase on nanoporous copper and its potential applications. Bioresour. Technol. 2010, 101, 9415-9420.

148. Hashemifard, N.; Mohsenifar, A.; Ranjbar, B.; Allameh, A.; Lotfi, A.S.; Etemadikia, B. Fabrication and kinetic studies of a novel silver nanoparticles-glucose oxidase bioconjugate. Anal. Chim. Acta 2010, 675, 181-184.

149. Singh, R.K.; Zhang, Y.W.; Nguyen, N.P.; Jeya, M.; Lee, J.K. Covalent immobilization of $\beta$-1,4-glucosidase from Agaricus arvensis onto functionalized silicon oxide nanoparticles. Appl. Microbiol. Biotechnol. 2010, 89, 337-344.

150. Zhang, Y.W.; Jeya, M.; Lee, J.K. Enhanced activity and stability of L-arabinose isomerase by immobilization on aminopropyl glass. Appl. Microbiol. Biotechnol. 2011, 89, 1435-1442.

151. Singh, V.; Ahmed, S. Silver nanoparticle (AgNPs) doped gum acacia-gelatin-silica nanohybrid: An effective support for diastase immobilization. Int. J. Biol. Macromol. 2011, 50, 353-361.

152. Wang, F.; Su, R.X.; Qi, W.; Zhang, M.J.; He, Z.M. Preparation and activity of bubbling-immobilized cellobiase within chitosan-alginate composite. Prep. Biochem. Biotechnol. 2010, 40, 57-64.

153. Ansari, S.A.; Husain, Q. Potential applications of enzymes immobilized on/in nano materials: A review. Biotechnol. Adv. 2012, 30, 512-523.

154. Nwagu, T.N.; Okolo, B.N.; Aoyagi, H. Stabilization of a raw starch digesting amylase from Aspergillus carbonarius via immobilization on activated and non-activated agarose gel. World J. Microbiol. Biotechnol. 2012, 28, 335-345.

155. Wang, A.; Wang, M.; Wang, Q.; Chen, F.; Zhang, F.; Li, H.; Zeng, Z.; Xie, T. Stable and efficient immobilization technique of aldolase under consecutive microwave irradiation at low temperature. Bioresour. Technol. 2011, 102, 469-474.

156. Shankar, S.K.; Praveen Kumar, S.K.; Mulimani, V.H. Calcium alginate entrapped preparation of $\alpha$-galactosidase: Its stability and application in hydrolysis of soymilk galactooligosaccharides. J. Ind. Microbiol. Biotechnol. 2011, 38, 1399-1405.

157. Cristovao, R.O.; Silverio, S.C.; Tavares, A.P.; Brigida, A.I.; Loureiro, J.M.; Boaventura, R.A.; Macedo, E.A.; Coelho, M.A. Green coconut fiber: A novel carrier for the immobilization of commercial laccase by covalent attachment for textile dyes decolourization. World J. Microbiol. Biotechnol. 2012, 28, 2827-2838. 
158. Sahoo, B.; Sahu, S.K.; Bhattacharya, D.; Dhara, D.; Pramanik, P. A novel approach for efficient immobilization and stabilization of papain on magnetic gold nanocomposites. Colloids Surf. B 2012, 101, 280-289.

159. Stark, M.B.; Holmberg, K. Covalent immobilization of lipase in organic solvents. Biotechnol. Bioeng. 1989, 34, 942-950.

160. Marcuello, C.; de Miguel, R.; Gomez-Moreno, C.; Martinez-Julvez, M.; Lostao, A. An efficient method for enzyme immobilization evidenced by atomic force microscopy. Protein Eng. Des. Sel. 2012, 25, 715-723.

161. Janssen, M.H.A.; van Langen, L.M.; Pereira, S.R.M.; van Rantwijk, F.; Sheldon, R.A. Evaluation of the performance of immobilized penicillin $G$ acylase using active-site titration. Biotechnol. Bioeng. 2002, 78, 425-432.

162. Bezbradica, D.; Mijin, D.; Mihailović, M.; Knežević-Jugović, Z. Microwave-assisted immobilization of lipase from Candida rugosa on Eupergit ${ }^{\circledR}$ supports. J. Chem. Technol. Biotechnol. 2009, 84, 1642-1648.

163. Itoyama, K.; Tokura, S.; Hayashi, T. Lipoprotein lipase immobilization onto porous chitosan beads. Biotechnol. Prog. 1994, 10, 225-229.

164. Hayashi, T.; Ikada, Y. Protease immobilization onto polyacrolein microspheres. Biotechnol. Bioeng. 1990, 35, 518-524.

165. Itoyama, K.; Tanibe, H.; Hayashi, T.; Ikada, Y. Spacer effects on enzymatic activity of papain immobilized onto porous chitosan beads. Biomaterials 1994, 15, 107-112.

166. Abian, O.; Wilson, L.; Mateo, C.; Fernández-Lorente, G.; Palomo, J.M.; Fernández-Lafuente, R.; Guisán, J.M.; Re, D.; Tam, A.; Daminatti, M. Preparation of artificial hyper-hydrophilic micro-environments (polymeric salts) surrounding enzyme molecules: New enzyme derivatives to be used in any reaction medium. J. Mol. Catal. B 2002, 19-20, 295-303.

167. Bigdeli, S.; Talasaz, A.H.; Ståhl, P.; Persson, H.H.J.; Ronaghi, M.; Davis, R.W.; Nemat-Gorgani, M. Conformational flexibility of a model protein upon immobilization on self-assembled monolayers. Biotechnol. Bioeng. 2008, 100, 19-27.

168. Cao, L.; Schmid, R.D. Carrier-Bound Immobilized Enzymes: Principles, Application and Design; Wiley-VCH Verlag: Weinheim, Germany, 2005.

169. Aksoy, S.; Tumturk, H.; Hasirci, N. Stability of $\alpha$-amylase immobilized on poly (methyl methacrylate-acrylic acid) microspheres. J. Biotechnol. 1998, 60, 37-46.

170. Hanefeld, U.; Gardossi, L.; Magner, E. Understanding enzyme immobilisation. Chem. Soc. Rev. 2009, 38, 453-468.

171. Sabularse, V.C.; Tud, M.T.; Lacsamana, M.S.; Solivas, J.L. Black and white lahar as inorganic support for the immobilization of yeast invertase. ASEAN J. Sci. Technol. Dev. 2005, 22, 331-344.

172. Kotwal, S.M.; Shankar, V. Immobilized invertase. Biotechnol. Adv. 2009, 27, 311-322.

173. Clark, D.S. Can immobilization be exploited to modify enzyme activity? Trends Biotechnol. 1994, 12, 439-443.

174. Mateo, C.; Palomo, J.M.; Fernandez-Lorente, G.; Guisan, J.M.; Fernandez-Lafuente, R. Improvement of enzyme activity, stability and selectivity via immobilization techniques. Enzyme Microb. Technol. 2007, 40, 1451-1463. 
175. Matsumoto, M.; Ohashi, K. Effect of immobilization on thermostability of lipase from Candida rugosa. Biochem. Eng. J. 2003, 14, 75-77.

176. Moriyama, S.; Noda, A.; Nakanishi, K.; Matsuno, R.; Kamikubo, T. Thermal stability of immobilized glucoamylase entrapped in polyacrylamide gels and bound to SP-Sephadex C-50. Agric. Biol. Chem. 1980, 44, 2024-2054.

177. Fruhwirth, G.O.; Paar, A.; Gudelj, M.; Cavaco-Paulo, A.; Robra, K.H.; Gübitz, G.M. An immobilised catalase peroxidase from the alkalothermophilic Bacillus SF for the treatment of textile-bleaching effluents. Appl. Microbiol. Biotechnol. 2002, 60, 313-319.

178. Fernandez-Lafuente, R.; Cowan, D.A.; Wood, A.N.P. Hyperstabilization of a thermophilic esterase by multipoint covalent attachment. Enzyme Microb. Technol. 1995, 17, 366-372.

179. Lee, D.C.; Lee, S.G.; Kim, H.S. Production of D-p-hydroxyphenylglycine from D,L-5-(4-hydroxyphenyl)hydantoin using immobilized thermostable D-hydantoinase from Bacillus stearothermophilus SD-1. Enzyme Microb. Technol. 1996, 18, 35-40.

180. Kawakami, K.; Abe, T.; Tomoaki, Y. Silicone-immobilized biocatalysts effective for bioconversions in nonaqueous media. Enzyme Microb. Technol. 1992, 14, 371-375.

181. Pedroche, J.; del Mar Yust, M.; Mateo, C.; Fernández-Lafuente, R.; Girán-Calle, J.; Alaiz, M.; Vioque, J.; Guisán, J.M.; Millán, F. Effect of the support and experimental conditions in the intensity of the multipoint covalent attachment of proteins on glyoxyl-agarose supports: Correlation between enzyme-support linkages and thermal stability. Enzyme Microb. Technol. 2007, 40, 1160-1166.

182. Mateo, C.; Abian, O.; Fernández-Lafuente, R.; Guisan, J.M. Increase in conformational stability of enzymes immobilized on epoxy-activated supports by favoring additional multipoint covalent attachment. Enzyme Microb. Technol. 2000, 26, 509-515.

183. Wang, P.; Hu, X.; Cook, S.; Hwang, H.M. Influence of silica-derived nano-supporters on cellobiase after immobilization. Appl. Biochem. Biotechnol. 2009, 158, 88-96.

184. Wong, L.S.; Khan, F.; Micklefield, J. Selective covalent protein immobilization: Strategies and applications. Chem. Rev. 2009, 109, 4025-4053.

185. Kahraman, M.V.; Bayramoğlu, G.; Kayaman-Apohan, N.; Güngör, A. $\alpha$-Amylase immobilization on functionalized glass beads by covalent attachment. Food Chem. 2007, 104, $1385-1392$.

186. Yilmaz, E.; Can, K.; Sezgin, M.; Yilmaz, M. Immobilization of Candida rugosa lipase on glass beads for enantioselective hydrolysis of racemic naproxen methyl ester. Bioresour. Technol. 2011, 102, 499-506.

187. Garcia, A., III; Oh, S.; Engler, C.R. Cellulase immobilization on $\mathrm{Fe}_{3} \mathrm{O}_{4}$ and characterization. Biotechnol. Bioeng. 1989, 33, 321-326.

188. Bolivar, J.M.; Wilson, L.; Ferrarotti, S.A.; Fernandez-Lafuente, R.; Guisan, J.M.; Mateo, C. Stabilization of a formate dehydrogenase by covalent immobilization on highly activated glyoxyl-agarose supports. Biomacromolecules 2006, 7, 669-673.

189. Tardioli, P.W.; Zanin, G.M.; de Moraes, F.F. Characterization of Thermoanaerobacter cyclomaltodextrin glucanotransferase immobilized on glyoxyl-agarose. Enzyme Microb. Technol. 2006, 39, 1270-1278. 
190. Pessela, B.C.; Mateo, C.; Fuentes, M.; Vian, A.; Garcia, J.L.; Carrascosa, A.V.; Guisan, J.M.; Fernandez-Lafuente, R. Stabilization of a multimeric $\beta$-galactosidase from Thermus sp. strain T2 by immobilization on novel heterofunctional epoxy supports plus aldehyde-dextran cross-linking. Biotechnol. Prog. 2004, 20, 388-392.

191. Guisán, J.M.; Polo, E.; Aguado, J.; Romero, M.D.; Álvaro, G.; Guerra, M.J. Immobilization-stabilization of thermolysin onto activated agarose gels. Biocatal. Biotransform. 1997, 15, 159-173.

192. Otero, C.; Ballesteros, A.; Guisán, J.M. Immobilization/stabilization of lipase from Candida rugosa. Appl. Biochem. Biotechnol. 1988, 19, 163-175.

193. Alvaro, G.; Fernandez-Lafuente, R.; Blanco, R.M.; Guisan, J.M. Immobilization-stabilization of penicillin G acylase from Escherichia coli. Appl. Biochem. Biotechnol. 1990, 26, 181-195.

194. Guisan, J.M.; Bastida, A.; Cuesta, C.; Fernandez-Lufuente, R.; Rosell, C.M. Immobilization-stabilization of $\alpha$-chymotrypsin by covalent attachment to aldehyde-agarose gels. Biotechnol. Bioeng. 1991, 38, 1144-1152.

195. Guisan, J.M.; Alvaro, G.; Fernandez-Lafuente, R.; Rosell, C.M.; Garcia, J.L.; Tagliani, A. Stabilization of heterodimeric enzyme by multipoint covalent immobilization: Penicillin G acylase from Kluyvera citrophila. Biotechnol. Bioeng. 1993, 42, 455-464.

196. Akgöl, S.; Bayramoğlu, G.; Kacar, Y.; Denizli, A.; Arıca, M.Y. Poly(hydroxyethyl methacrylateco-glycidyl methacrylate) reactive membrane utilised for cholesterol oxidase immobilisation. Polym. Int. 2002, 51, 1316-1322.

197. Tardioli, P.W.; Pedroche, J.; Giordano, R.L.; Fernandez-Lafuente, R.; Guisan, J.M. Hydrolysis of proteins by immobilized-stabilized alcalase-glyoxyl agarose. Biotechnol. Prog. 2003, 19, 352-360.

198. Suh, C.W.; Choi, G.S.; Lee, E.K. Enzymic cleavage of fusion protein using immobilized urokinase covalently conjugated to glyoxyl-agarose. Biotechnol. Appl. Biochem. 2003, 37, 149-155.

199. Bayramoglu, G.; Yilmaz, M.; Arica, M.Y. Immobilization of a thermostable $\alpha$-amylase onto reactive membranes: Kinetics characterization and application to continuous starch hydrolysis. Food Chem. 2004, 84, 591-599.

200. Danisman, T.; Tan, S.; Kacar, Y.; Ergene, A. Covalent immobilization of invertase on microporous pHEMA-GMA membrane. Food Chem. 2004, 85, 461-466.

201. De Segura, A.G.; Alcalde, M.; Yates, M.; Rojas-Cervantes, M.L.; López-Cortés, N.; Ballesteros, A.; Plou, F.J. Immobilization of dextransucrase from Leuconostoc mesenteroides NRRL B-512F on Eupergit C Supports. Biotechnol. Prog. 2004, 20, 1414-1420.

202. Bolivar, J.M.; Wilson, L.; Ferrarotti, S.A.; Guisan, J.M.; Fernandez-Lafuente, R.; Mateo, C. Improvement of the stability of alcohol dehydrogenase by covalent immobilization on glyoxyl-agarose. J. Biotechnol. 2006, 125, 85-94.

203. Ferrarotti, S.A.; Bolivar, J.M.; Mateo, C.; Wilson, L.; Guisan, J.M.; Fernandez-Lafuente, R. Immobilization and stabilization of a cyclodextrin glycosyltransferase by covalent attachment on highly activated glyoxyl-agarose supports. Biotechnol. Prog. 2006, 22, 1140-1145.

204. Bolivar, J.M.; Wilson, L.; Ferrarotti, S.A.; Fernandez-Lafuente, R.; Guisan, J.M.; Mateo, C. Evaluation of different immobilization strategies to prepare an industrial biocatalyst of formate dehydrogenase from Candida boidinii. Enzyme Microb. Technol. 2007, 40, 540-546. 
205. Arica, M.Y.; Altintas, B.; Bayramoglu, G. Immobilization of laccase onto spacer-arm attached non-porous poly(GMA/EGDMA) beads: Application for textile dye degradation. Bioresour. Technol. 2009, 100, 665-669.

206. Zhang, Y.W.; Tiwari, M.K.; Jeya, M.; Lee, J.K. Covalent immobilization of recombinant Rhizobium etli CFN42 xylitol dehydrogenase onto modified silica nanoparticles. Appl. Microbiol. Biotechnol. 2010, 90, 499-507.

207. Corman, M.E.; Ozturk, N.; Bereli, N.; Akgol, S.; Denizli, A. Preparation of nanoparticles which contains histidine for immobilization of Trametes versicolor laccase. J. Mol. Catal. B 2010, 63, 102-107.

208. Zhou, J. Immobilization of cellulase on a reversibly soluble-insoluble support: Properties and application. J. Agric. Food Chem. 2010, 58, 6741-6746.

209. Fu, J.; Reinhold, J.; Woodbury, N.W. Peptide-modified surfaces for enzyme immobilization. PLoS One 2011, 6, e18692.

210. Mendes, A.A.; Freitas, L.; de Carvalho, A.K.; de Oliveira, P.C.; de Castro, H.F. Immobilization of a commercial lipase from Penicillium camembertii (lipase G) by different strategies. Enzyme Res. 2011, 2011, 967239:1-967239:8.

211. Menezes-Blackburn, D.; Jorquera, M.; Gianfreda, L.; Rao, M.; Greiner, R.; Garrido, E.; de la Luz Mora, M. Activity stabilization of Aspergillus niger and Escherichia coli phytases immobilized on allophanic synthetic compounds and montmorillonite nanoclays. Bioresour. Technol. 2011, 102, 9360-9367.

212. Madadlou, A.; Iacopino, D.; Sheehan, D.; Emam-Djomeh, Z.; Mousavi, M.E. Enhanced thermal and ultrasonic stability of a fungal protease encapsulated within biomimetically generated silicate nanospheres. Biochim. Biophys. Acta 2010, 1800, 459-465.

213. Xue, Y.; Nie, H.; Zhu, L.; Li, S.; Zhang, H. Immobilization of modified papain with anhydride groups on activated cotton fabric. Appl. Biochem. Biotechnol. 2010, 160, 109-121.

214. Tananchai, P.; Chisti, Y. Stabilization of invertase by molecular engineering. Biotechnol. Prog. 2010, 26, 111-117.

215. Kikani, B.A.; Pandey, S.; Singh, S.P. Immobilization of the $\alpha$-amylase of Bacillus amyloliquifaciens TSWK1-1 for the improved biocatalytic properties and solvent tolerance. Bioprocess Biosyst. Eng. 2012, doi:10.1007/s00449-012-0812-3.

216. Khalaf, N.; Govardhan, C.P.; Lalonde, J.J.; Persichetti, R.A.; Wang, Y.F.; Margolin, A.L. Cross-linked enzyme crystals as highly active catalysts in organic solvents. J. Am. Chem. Soc. 1996, 118, 5494-5495.

217. Sheldon, R.A. Enzyme immobilization: The quest for optimum performance. Adv. Synth. Catal. 2007, 349, 1289-1307.

218. Bommarius, A.S.; Karau, A. Deactivation of formate dehydrogenase (FDH) in solution and at gas-liquid interfaces. Biotechnol. Prog. 2005, 21, 1663-1672.

219. Caussette, M.; Gaunand, A.; Planche, H.; Monsan, P.; Lindet, B. Inactivation of enzymes by inert gas bubbling: A kinetic study. Ann. N. Y. Acad. Sci. 1998, 864, 228-233.

220. Orsat, B.; Drtina, G.J.; Williams, M.G.; Klibanov, A.M. Effect of support material and enzyme pretreatment on enantioselectivity of immobilized subtilisin in organic solvents. Biotechnol. Bioeng. 1994, 44, 1265-1269. 
221. Ruiz, A.I.; Malavé, A.J.; Felby, C.; Griebenow, K. Improved activity and stability of an immobilized recombinant laccase in organic solvents. Biotechnol. Lett. 2000, 22, 229-233.

222. Prodanovic, R.M.; Milosavic, N.B.; Jovanovic, S.M.; Velickovic, T.C.; Vujcic, Z.M.; Jankov, R.M. Stabilization of $\alpha$-glucosidase in organic solvents by immobilization on macroporous poly(GMA-co-EGDMA) with different surface characteristics. J. Serb. Chem. Soc. 2006, 71, 339-347.

223. Lo, Y.S.; Ibrahim, C.O. Some characteristics of amberlite XAD-7-adsorbed lipase from Pseudomonas sp. AK. Malays. J. Microbiol. 2005, 1, 53-56.

224. Rozzell, J.D. Commercial scale biocatalysis: Myths and realities. Bioorg. Med. Chem. 1999, 7 , 2253-2261.

225. Takac, S.; Bakkal, M. Impressive effect of immobilization conditions on the catalytic activity and enantioselectivity of Candida rugosa lipase toward S-Naproxen production. Process Biochem. 2007, 42, 1021-1027.

226. Reetz, M.T.; Zonta, A.; Schimossek, K.; Jaeger, K.E.; Liebeton, K. Creation of enantioselective biocatalysts for organic chemistry by in vitro evolution. Angew. Chem. Int. Ed. 1997, 36, 2830-2832.

227. Palomo, J.M.; Fernandez-Lorente, G.; Mateo, C.; Ortiz, C.; Fernandez-Lafuente, R.; Guisan, J.M. Modulation of the enantioselectivity of lipases via controlled immobilization and medium engineering: Hydrolytic resolution of mandelic acid esters. Enzyme Microb. Technol. 2002, 31, 775-783.

228. Nishio, T.; Hayashi, R. Digestion of protein substrates by subtilisin: Immobilization changes the pattern of products. Arch. Biochem. Biophys. 1984, 229, 304-311.

229. Hernaiz, M.J.; Crout, D.H.G. A highly selective synthesis of N-acetyllactosamine catalyzed by immobilised $\beta$-galactosidase from Bacillus circulans. J. Mol. Catal. B 2000, 10, 403-408.

230. Boundy, J.A.; Smiley, K.L.; Swanson, C.L.; Hofreiter, B.T. Exoenzymic activity of $\alpha$-amylase immobilized on a phenol-formaldehyde resin. Carbohydr. Res. 1976, 48, 239-244.

231. Linko, Y.Y.; Saarinen, P.; Linko, M. Starch conversion by soluble and immobilized $\alpha$-amylase. Biotechnol. Bioeng. 1975, 17, 153-165.

232. Rotticci, D.; Norin, T.; Hult, K. Mass transport limitations reduce the effective stereospecificity in enzyme-catalyzed kinetic resolution. Org. Lett. 2000, 2, 1373-1376.

233. Ogino, S. Formation of the fructose-rich polymer by water-insoluble dextransucrease and presence of glycogen valuelowering factor. Agric. Biol. Chem. 1970, 34, 1268-1271.

234. Palomo, J.M.; Segura, R.L.; Mateo, C.; Terreni, M.; Guisan, J.M.; Fernández-Lafuente, R. Synthesis of enantiomerically pure glycidol via a fully enantioselective lipase-catalyzed resolution. Tetrahedron Asymmetry 2005, 16, 869-874.

235. Palomo, J.M.; Segura, R.L.; Fernandez-Lorente, G.; Guisan, J.M.; Fernandez-Lafuente, R. Enzymatic resolution of $( \pm)$-glycidyl butyrate in aqueous media. Strong modulation of the properties of the lipase from Rhizopus oryzae via immobilization techniques. Tetrahedron Asymmetry 2004, 15, 1157-1161.

236. Palomo, J.M.; Fernández-Lorente, G.; Rúa, M.L.; Guisún, J.M.; Fernández-Lafuente, R. Evaluation of the lipase from Bacillus thermocatenulatus as an enantioselective biocatalyst. Tetrahedron Asymmetry 2003, 14, 3679-3687. 
237. Palomo, J.M.; Muáoz, G.; Fernádez-Lorente, G.; Mateo, C.; Fuentes, M.; Guisan, J.M.; Fernández-Lafuente, R. Modulation of Mucor miehei lipase properties via directed immobilization on different hetero-functional epoxy resins: Hydrolytic resolution of (R,S)-2-butyroyl-2-phenylacetic acid. J. Mol. Catal. B 2003, 21, 201-210.

238. Palomo, J.M.; Segura, R.L.; Fernandez-Lorente, G.; Fernandez-Lafuente, R.; Guisán, J.M. Glutaraldehyde modification of lipases adsorbed on aminated supports: A simple way to improve their behaviour as enantioselective biocatalyst. Enzyme Microb. Technol. 2007, 40, 704-707.

239. Cabrera, Z.; Fernandez-Lorente, G.; Fernandez-Lafuente, R.; Palomo, J.M.; Guisan, J.M. Novozym 435 displays very different selectivity compared to lipase from Candida antarctica B adsorbed on other hydrophobic supports. J. Mol. Catal. B 2009, 57, 171-176.

240. Sahin, O.; Erdemir, S.; Uyanik, A.; Yilmaz, M. Enantioselective hydrolysis of $(R / S)$-Naproxen methyl ester with sol-gel encapsulated lipase in presence of calix[n]arene derivatives. Appl. Catal. A 2009, 369, 36-41.

241. Wang, P.Y.; Tsai, S.W.; Chen, T.L. Improvements of enzyme activity and enantioselectivity via combined substrate engineering and covalent immobilization. Biotechnol. Bioeng. 2008, 101, 460-469.

242. Partridge, J.; Halling, P.J.; Moore, B.D. Practical route to high activity enzyme preparations for synthesis in organic media. Chem. Commun. 1998, 841-842, doi:10.1039/A800408K.

243. Ursini, A.; Maragni, P.; Bismara, C.; Tamburini, B. Enzymatic method of preparation of opticallly active trans-2-amtno cyclohexanol derivatives. Synth. Commun. 1999, 29, 1369-1377.

244. Mateo, C.; Monti, R.; Pessela, B.C.C.; Fuentes, M.; Torres, R.; Guisán, J.M.; Fernández-Lafuente, R. Immobilization of lactase from Kluyveromyces lactis greatly reduces the inhibition promoted by glucose. Full hydrolysis of lactose in milk. Biotechnol. Prog. 2004, 20, 1259-1262.

245. Pessela, B.C.C.; Mateo, C.; Fuentes, M.; Vian, A.; Garcia, J.L.; Carrascosa, A.V.; Guisan, J.M.; Fernandez-Lafuente, R. The immobilization of a thermophilic $\beta$-galactosidase on Sepabeads supports decreases product inhibition: Complete hydrolysis of lactose in dairy products. Enzyme Microb. Technol. 2003, 33, 199-205.

246. Brazeau, B.J.; de Souza, M.L.; Gort, S.J.; Hicks, P.M.; Kollmann, S.R.; Laplaza, J.M.; McFarlan, S.C.; Sanchez-Riera, F.A.; Solheid, C. Polypeptides and Biosynthetic Pathways for the Production of Stereoisomers of Monatin and Their Precursors. U.S. Patent 20080020434, 24 January 2008.

247. Cho, E.J.; Jung, S.; Kim, H.J.; Lee, Y.G.; Nam, K.C.; Lee, H.J.; Bae, H.J. Co-immobilization of three cellulases on Au-doped magnetic silica nanoparticles for the degradation of cellulose. Chem. Commun. 2012, 48, 886-888.

248. Betancor, L.; Berne, C.; Luckarift, H.R.; Spain, J.C. Coimmobilization of a redox enzyme and a cofactor regeneration system. Chem. Commun. 2006, 3640-3642, doi:10.1039/b604689d.

249. St. Clair, N.; Wang, Y.F.; Margolin, A.L. Cofactor-bound cross-linked enzyme crystals (CLEC) of alcohol dehydrogenase. Angew. Chem. Int. Ed. 2000, 39, 380-383.

250. Van Dongen, S.F.M.; Nallani, M.; Cornelissen, J.J.L.M.; Nolte, R.J.M.; van Hest, J.C.M. A three-enzyme cascade reaction through positional assembly of enzymes in a polymersome nanoreactor. Chem. Eur. J. 2009, 15, 1107-1114. 
251. Brady, D.; Jordaan, J.; Simpson, C.; Chetty, A.; Arumugam, C.; Moolman, F.S. Spherezymes: A novel structured self-immobilisation enzyme technology. BMC Biotechnol. 2008, $8,8$.

252. Pundir, C.S.; Chauhan, N. Coimmobilization of detergent enzymes onto a plastic bucket and brush for their application in cloth washing. Ind. Eng. Chem. Res. 2012, 51, 3556-3563.

253. Minakshi; Pundir, C.S. Co-immobilization of lipase, glycerol kinase, glycerol-3-phosphate oxidase and peroxidase on to aryl amine glass beads affixed on plastic strip for determination of triglycerides in serum. Indian J. Biochem. Biophys. 2008, 45, 111-115.

254. Park, D.; Haam, S.; Jang, K.; Ahn, I.S.; Kim, W.S. Immobilization of starch-converting enzymes on surface-modified carriers using single and co-immobilized systems: Properties and application to starch hydrolysis. Process Biochem. 2005, 40, 53-61.

255. Larsen, G.; Velarde-Ortiz, R.; Minchow, K.; Barrero, A.; Loscertales, I.G. A method for making inorganic and hybrid (organic/inorganic) fibers and vesicles with diameters in the submicrometer and micrometer range via sol-gel chemistry and electrically forced liquid jets. J. Am. Chem. Soc. 2003, 125, 1154-1155.

256. Kim, J.; Grate, J.W.; Wang, P. Nanostructures for enzyme stabilization. Chem. Eng. Sci. 2006, $61,1017-1026$.

257. Kim, J.; Grate, J.W.; Wang, P. Nanobiocatalysis and its potential applications. Trends Biotechnol. 2008, 26, 639-646.

258. Hwang, E.T.; Tatavarty, R.; Lee, H.; Kim, J. Shape reformable polymeric nanofibers entrapped with QDs as a scaffold for enzyme stabilization. J. Mater. Chem. 2011, 21, 5215-5218.

259. Lee, S.M.; Jin, L.H.; Kim, J.H.; Han, S.O.; Na, H.B.; Hyeon, T.; Koo, Y.M.; Kim, J.; Lee, J.H. $\beta$-glucosidase coating on polymer nanofibers for improved cellulosic ethanol production. Bioprocess Biosyst. Eng. 2010, 33, 141-147.

260. Woo, E.; Ponvel, K.M.; Ahn, I.; Lee, C. Synthesis of magnetic/silica nanoparticles with a core of magnetic clusters and their application for the immobilization of His-tagged enzymes. J. Mater. Chem. 2010, 20, 1511-1515.

261. Herricks, T.E.; Kim, S.; Kim, J.; Li, D. Direct fabrication of enzyme-carrying polymer nanofibers by electrospinning. J. Mater. Chem. 2005, 15, 3241-3245.

262. Martinek, K.; Mozhaev, V.V. Practice importance of enzyme stability. 2. Increase of enzyme stability by immobilization and treatment with low-molecularweight reagents. Pure Appl. Chem. 1991, 63, 1533-1537.

263. Dallinger, D.; Kappe, C.O. Microwave-assisted synthesis in water as solvent. Chem. Rev. 2007, 107, 2563-2591.

264. Galinada, W.A.; Guiochon, G. Influence of microwave irradiation on the intraparticle diffusion of an insulin variant in reversed-phase liquid chromatography under linear conditions. J. Chromatogr. A 2007, 1163, 157-168.

265. Varma, R.S.; Saini, R.K. Microwave-assisted reduction of carbonyl compounds in solid state using sodium borohydride supported on alumina. Tetrahedron Lett. 1997, 38, 4337-4338.

266. Varma, R.S.; Dahiya, R.; Saini, R.K. Lodobenzene diacetate on alumina: Rapid oxidation of alcohols to carbonyl compounds in solventless system using microwaves. Tetrahedron Lett. 1997, 38, 7029-7032. 
267. Wang, A.; Wang, H.; Zhu, S.; Zhou, C.; Du, Z.; Shen, S. An efficient immobilizing technique of penicillin acylase with combining mesocellular silica foams support and $p$-benzoquinone cross linker. Bioprocess Biosyst. Eng. 2008, 31, 509-517.

268. Wang, A.; Liu, M.; Wang, H.; Zhou, C.; Du, Z.; Zhu, S.; Shen, S.; Ouyang, P. Improving enzyme immobilization in mesocellular siliceous foams by microwave irradiation. J. Biosci. Bioeng. 2008, 106, 286-291.

269. Nahar, P.; Bora, U. Microwave-mediated rapid immobilization of enzymes onto an activated surface through covalent bonding. Anal. Biochem. 2004, 328, 81-83.

270. Naqvi, A.; Nahar, P. Photochemical immobilization of proteins on microwave-synthesized photoreactive polymers. Anal. Biochem. 2004, 327, 68-73.

271. Kumar, S.; Nahar, P. Sunlight-induced covalent immobilization of proteins. Talanta 2007, 71, $1438-1440$.

272. Tanaka, Y.; Tsuruda, Y.; Nishi, M.; Kamiya, N.; Goto, M. Exploring enzymatic catalysis at a solid surface: A case study with transglutaminase-mediated protein immobilization. Org. Biomol. Chem. 2007, 5, 1764-1770.

273. Wong, L.S.; Thirlway, J.; Micklefield, J. Direct site-selective covalent protein immobilization catalyzed by a phosphopantetheinyl transferase. J. Am. Chem. Soc. 2008, 130, 12456-12464.

274. Bolivar, J.M.; Hidalgo, A.; Sanchez-Ruiloba, L.; Berenguer, J.; Guisan, J.M.; Lopez-Gallego, F. Modulation of the distribution of small proteins within porous matrixes by smart-control of the immobilization rate. J. Biotechnol. 2011, 155, 412-420.

275. Rocha-Martín, J.; de las Rivas, B.; Muñoz, R.; Guisán, J.M.; López-Gallego, F. Rational co-immobilization of bi-enzyme cascades on porous supports and their applications in bio-redox reactions with in situ recycling of soluble cofactors. ChemCatChem 2012, 4, 1279-1288.

276. Dalal, S.; Kapoor, M.; Gupta, M.N. Preparation and characterization of combi-CLEAs catalyzing multiple non-cascade reactions. J. Mol. Catal. B 2007, 44, 128-132.

277. Forster, A.C.; Church, G.M. Synthetic biology projects in vitro. Genome Res. 2007, 17, 1-6.

278. Gore, J.; van Oudenaarden, A. Synthetic biology: The yin and yang of nature. Nature 2009, 457, 271-272.

279. Godoy, C.A.; de las Rivas, B.; Grazu, V.; Montes, T.; Guisan, J.M.; Lopez-Gallego, F. Glyoxyl-disulfide agarose: A tailor-made support for site-directed rigidification of proteins. Biomacromolecules 2011, 12, 1800-1809.

(C) 2013 by the authors; licensee MDPI, Basel, Switzerland. This article is an open access article distributed under the terms and conditions of the Creative Commons Attribution license (http://creativecommons.org/licenses/by/3.0/). 